\title{
Determinants of the Land Registration Information System Operational Success: Empirical Evidence from Ethiopia
}

\author{
Shewakena Aytenfisu Abab *, Feyera Senbeta Wakjira and Tamirat Tefera Negash \\ Center for Environment and Development, College of Development Studies, Addis Ababa University, \\ Addis Ababa P.O. Box 1176, Ethiopia; feyera.senbeta@aau.edu.et (F.S.W.); tamirat.tefera@aau.edu.et (T.T.N.) \\ * Correspondence: shewakena.aytenfisu@aau.edu.et
}

Citation: Abab, S.A.; Wakjira, F.S.; Negash, T.T. Determinants of the Land Registration Information System Operational Success: Empirical Evidence from Ethiopia. Land 2021, 10, 1394. https://doi.org/ $10.3390 /$ land 10121394

Academic Editors: Uchendu Eugene Chigbu, Ruishan Chen and Chao Ye

Received: 28 October 2021

Accepted: 10 December 2021

Published: 16 December 2021

Publisher's Note: MDPI stays neutra with regard to jurisdictional claims in published maps and institutional affiliations.

Copyright: (c) 2021 by the authors. Licensee MDPI, Basel, Switzerland. This article is an open access article distributed under the terms and conditions of the Creative Commons Attribution (CC BY) license (https:/ / creativecommons.org/licenses/by/ $4.0 /)$.

\begin{abstract}
Ethiopia has embarked on one of the largest digitalization programs for rural land registration in Africa. The program is called the national rural land administration information system (NRLAIS). Over the past couple of years, NRLAIS was rolled-out and made operational in over 180 woredas (districts). There is, however, limited empirical evidence on whether and to what extent NRLAIS has been successful. This study explores the factors that influence the acceptance and actual use of NRLAIS to gauge its operational success in Ethiopia. Data were collected both from primary and secondary sources using surveys, key informant interviews, and a literature review. Survey data were collected from 201 staff of 50 woreda land administration offices in three regional states (Amhara, Oromia, and SNNP) and analyzed using a structural equation model. The results revealed that system quality, information quality, service quality, and perceived usefulness of NRLAIS have positively and significantly influenced the acceptance and actual use of the system. However, perceived ease of use has an insignificant influence. The predictive relevance of the research model is significant and indicates substantial operational success of NRLAIS. The quick acceptance and use of NRLAIS will likely improve service delivery, promote data integration, and strengthen informed decision-making. The study recommends strengthening behavioral changes of the land administration experts through two enhanced service quality measures-technical and operational capacity to a robust and sustainable digitalization. Policymakers could leverage operational success to upgrade the NRLAIS into a unified national land registration information system that bridges the urban-rural land governance divide.
\end{abstract}

Keywords: land register; digitalization; standardization; tenure security; service delivery; governance; structural equation model

\section{Introduction}

Land is a key natural resource, means of livelihood, and development asset for many societies in Ethiopia. The relationship between people and land also bisects almost all sustainable development goals (SDGs) [1,2]. The SDGs and other recent global initiatives have renewed and increased the need to improve land tenure to address a multitude of development challenges [3]. Secure land tenure has regularly been prioritized by policymakers to ensure long-term land-based investment, agricultural productivity, as well as to address changing climate risks, biodiversity loss, poverty reduction, food security, and spur sustainable growth [3-6].

Traditionally, land administration systems were created to record information about property ownership, rights, and boundaries, and other attributes of real properties [7]. However, depending on the context, the strengthening of land rights can take a variety of forms, from documenting customary uses to formalizing individual rights [3]. In other instances, existing customary land tenure systems may be sufficient to ensure land tenure security [8]. Land registration and information system programs and procedures to implement these programs are among the major reasons for failure or success to achieve 
stronger tenure security [6]. Thus, land registration and information system organization should be part of studies on land tenure and investment in land and productivity [9].

Land information systems (LIS) in this paper are understood as a set of land information technologies (hardware, software, infrastructure, and equipment), personnel, data, rules-based procedures, and organizational structures. The existence of good and wellfunctioning land information infrastructure is key to answering the fundamental land development and management decision-making questions (i.e., why, who, what, where, when, and how) [10]. The LIS should be complete, reliable, uniform, up to date, and sustainable [11]. Accurate and up-to-date land administration data are also understood as occurring between land information system establishment and maintenance phases [12]. Hence, LIS needs to reflect the reality on the ground and transform itself into a dynamic and sustainable innovation hub and meet service expectations $[13,14]$.

However, it is worth noting that the overall establishment, effectiveness, and maintenance of an integrated geospatial land information system depends on governance, technology, and people factors $[15,16]$. The governance factor further decomposes to the establishment of appropriate policy, legal framework, and governance structures, while the technological aspects include the data, innovation, and standards. The people dimension is concerned with capacity building, education, partnership, communication, and engagement [2]. Particularly, understanding factors influencing the intention of personnel to accept and use the system is important for the digital transformation and effective land administration service deliveries [17].

In the land registration and land tenure discourse, the 1970s and 1980s marked a move from a paper-based and manual type of data management and process to digital and automated systems in developed economies [1]. Many attempts have been made to set up titling systems in numerous African countries in the same period [18]. However, the efforts have largely failed to achieve the expected transformation, owing to colonial imported rules and systems that disregard local context, among other reasons $[19,20]$. In most cases, land registries failed to provide authoritative records of titles and transactions and quickly became outdated due to poor planning, lack of capacity, and the flouting and manipulation of law by officials and elites [21].

Despite low coverage of land registration in Africa (only 10\%), the surge of land titling programs following the recent reform of land policy and legal framework, such as in Ethiopia and Rwanda, have shown positive trends and outcomes [19,22]. The reform provides a rapid scale-up across the continent that improves access to land and tenure security [19]. These approaches take different forms, ranging from fit-for-purpose to propoor land recordation approaches [22-24]. Advancements in information technology have also facilitated the speedy acquisition, storage, dissemination, and application of data related to tenure, use, value, as well as the development of land and other natural resource governance [25]. Demands for a more customer-oriented focus is also one of the drivers for the automation of the land administration systems [1,15]. In this regard, a first step in introducing a new information technology (IT)-enabled land administration system is the determination of the user needs [7]. Hence, if LIS is to be successful, it will be designed to fulfill the requirements of its end-users [14]. Evidence shows that some African countries such as Rwanda and Ethiopia have launched modernization initiatives for their land information systems [13]. These countries accelerate and securely register land titles into a functional land registration information system [26,27].

In Ethiopia, at the heart of the land administration reform is the digitalization of the manual land register. Recognizing the manual land register shortcomings related to the maintenance, security, accessibility, and integration of land information at different administration levels, the Ministry of Agriculture (MoA) has opted for digitalization. Between 2015 and 2017, the MoA has developed and successfully piloted the national rural land administration information system (NRLAIS) in the highland regions [28]. NRLAIS is a web-based system developed on open-source licensed software and based on the land administration domain model (LADM). Hence, NRLAIS is the programmatic approach 
of the MoA to address the shortcomings of the semi-manual land register, improve the standardization of service delivery, and promote informed policymaking [28].

While the transition to the NRLAIS is at an initial stage, its operational success has not been researched based on explanation and prediction theories. There is little knowledge about what causes user acceptance and actual use of the NRLAIS in the land administration domain. It is also not know why and how the woreda land administration experts choose to discontinue the use of the semi-manual land register that they are using currently. There are a few similar studies in Africa such as Zeng and Cleon [17] on the implementation and development of land information systems (LIS) in Liberia, which adopted the diffusion paradigm. To the best of the authors' knowledge, this is the first attempt in the country. Taking the woreda land administration experts as a unit of analysis, the study seeks to understand the behavior of the woreda land administration experts towards the acceptance and actual use of the NRLAIS and document its operational success. The proposed and empirically tested model of this study reveals a strong construct validity and predictive power. The model captures multiple aspects of each variable, which is a change from much of the measurement of LIS success model constructs that focus on only one aspect of the construct. The study also highlights the needed policy and strategic actions to achieve robust and sustainable digitalization.

\section{Literature Review}

\subsection{Land Tenure and Registration in Ethiopia}

Dominated by the agricultural economy, the available scholarly literature documents that widespread tenure insecurity hinders long-term land-based investment in rural Ethiopia [28]. Land tenure insecurity contributes to unprecedented environmental degradation, ecosystem depletion, biodiversity loss, decrease in productivity, and food insecurity [28-31]. These development challenges have been compounded and amplified by climate change and disaster risks that threaten the sustainability of productive landscapes and livelihood resilience [32]. This section briefly highlights the historical account of land tenure and the land certification program and its implication to NRLAIS development in Ethiopia.

During the last century, the land tenure history of Ethiopia has experienced extensive changes. Ethiopia has a long legacy of state intervention in land tenure relations that influence local tenure regimes throughout different political discourses [33]. Hence, the creation and recording of land rights by the national state has been a development theme since the 1960s in the contemporary land tenure history of Ethiopia [34]. The land tenure registration innovations before 1960 have generally been swept away by subsequent changes, but they still have relevance as the model of tenure reform. Before the 1974 revolution, the land tenure systems of Ethiopia were grounded in historically shaped, local institutions, complex and varied across the regions [31]. The military socialist regime's redistributive land reform of 1975 ensured that rural farming households received access to land through only usufruct rights, while ensuring state ownership. Notably, this reform legacy not only weakened the remaining customary institutions but also swept away the overall imperial land governance systems [35]. The current land registration system is highly affected by the 1975 radical land reform of the military socialist regime (1974 to 1991).

In post-socialist Ethiopia, tenure insecurity is linked to a history of limited empowerment of smallholder farmers and significant control by the state in determining access to and control over land resources [35]. During the Ethiopia Revolutionary Democratic Front (EPRDF)-led government (1991 to 2018), state ownership was maintained and enshrined in the 1995 constitution. The 1995 constitution of the federal democratic republic of Ethiopia Article 40 inherited the state land ownership and usufruct rights for landholders from the military socialist regime. The governance structure also changed from a centralized socialistic arrangement to market-led decentralization [36]. Article 52 of the 1995 constitution gives the regional governments the right to administer land and other natural resources following the federal laws. As a result, the land tenure system is evolving differently in rural 
and urban areas [37]. Different federal proclamations govern its development, and reforms have been progressing at different speeds across the country [38,39]. Moreover, there are essentially two parallel land registration and information system infrastructures-one for rural and one for urban. This rural-urban divide costs the country hugely in terms of policy, institutional, technical, operational, and human resource challenges for integrated and transparent land administration and resource governance systems that foster sustainable development [29].

In rural Ethiopia, the theme of this research, the government has been implementing a progressive two-stage land registration and certification program since 1998 [30]. The first-level landholding certification (FLLC) program that started in 1998 has been claimed by the Government of Ethiopia $(\mathrm{GoE})$ as a policy response of improving tenure security to reverse land degradation, food insecurity, and poverty reduction [40]. Till 2010, the FLLC, which claimed to be cheap and fast, has mainly been financed by regional states but without spatial data of parcels $[33,34]$, whereas the second level landholding certification (SLLC) is being coordinated by the Federal Government in collaboration with the regional states and has attracted strong technical and financial support from international development partners [41]. The latter approach introduced parcel-level cadastral mapping and the transition of the manual registry into a harmonized computerized LIS [42]. Since 2013, Ethiopia has continued investing in the SLLC program to cover over 50 million rural parcels and improve tenure security and land administration service delivery [40,42]. According to MoA [43], between 2013 and 2021, over 21 million rural parcels have been demarcated and mapped, of which close to 18 million parcels have been issued with SLLC. The demarcation and mapping cover about 42 percent of the estimated 50 million parcels found in the highland parts of the country. In Ethiopia, the household-level positive impact of these massive land certification programs has been well studied by different scholars [33,40,41].

\subsection{Land Information System in Ethiopia}

In Ethiopia, the land registration information system (LRIS) follows the rural-urban cadastral divide. NRLAIS was developed for rural land and the cadaster and real property registration system (CRPRS) for urban land. The systems are being administered by two different agencies. NRLAIS is operated by the rural land administration agencies under the guidance of MoA, while CRPRS is operated by the Urban Land and Cadaster Chief Executive Officer under the guidance of the Ministry of Urban and Infrastructure Development (MoUID). The focus of this paper is NRLAIS serving rural land administration.

In 2010, MoA developed its information system/information communication technology (IS/ICT) and software development strategy for the first time [28]. The strategy was developed following analysis of the requirements of a harmonized land administration system that is suitable for the adoption and implementation of a unified LIS in Ethiopia. According to MoA [28], this IS/ICT strategy provides a single overarching requisite framework embracing both urban and rural lands for the safe and secure maintenance and updating of land records. However, following legal mandates MoA revised its IS/ICT and software development and implementation strategy twice, i.e., in 2012 and, later, in 2017, with a focus on rural land.

As part of the standardization of the rural land administration system, the development of NRLAIS was well established based on the analysis and business reengineering of the four existing organizational structures (federal, regional, zonal, and woreda) [28]. NRLAIS is a web-based system developed on open-source licensed software and based on the land administration domain model (LADM). The system utilizes a modular technology stack and meets the functional and legal requirements for registering rural landholding rights in all the non-pastoral and highland regional states of Ethiopia. The definition of technical specifications for the development of NRLAIS considered the requirements of the functional and legal framework at both the federal and regional levels, including inheritance, gift, exchange, divorce, rent, and encumbrances. 
Between 2015 and 2017, supported by the Finnish government-financed project Responsible and Innovative Land Administration in Ethiopia (REILA), MoA developed and piloted NRLAIS. A production version was delivered with an operational acceptance report (OAR) to the then MoA in March 2018 [44]. Between 2016 and 2017, NRLAIS has undergone due diligence processes through a series of pilot testing and upgrades. Since late 2018, the MoA initiated the rollout of NRLAIS into more regions and woredas. The NRLAIS roll-out was divided into two phases of two years each, starting with a comparative trial of four-to-six months that may reveal necessary improvements and changes, followed by a one-and-a-half year period for full-scale roll-out at national level. Since 2020, the second phase of the rollout has continued at increasing speed, addressing sustainability factors such as capacity building and upgrading of the software with emerging functionality requirements [28,43].

According to MoA [28], up to 400 woredas covering 25 million parcels of land records are targeted to establish a functional and operational NRLAIS by 2024. NRLAIS is operational in over 180 woredas of Amhara, Beneshangul Gumuz, Oromia, Southern Nations Nationalities and Peoples (SNNP), and Tigray regional states as of November 2021 [43]. By mid-2021, about 113 woredas with NRLAIS have been verified by third party or independent verifying agency for the system being made operational. During the same period, the information from approximately 11 million parcels has been migrated into the system, 5 to 13 subsequent land transactions were updated per day per woreda, and over 102,000 transactions per year were updated in total. NRLAIS is the largest distributed LIS in Ethiopia and currently operates in 6 regional states, 37 Zones, and over 180 woredas. However, the wider area network (WAN) that connect woredas to zonal, regional to federal/central servers for an online data replication and information flow is yet to deployed due to underdeveloped network infrastructure in the country.

NRLAIS will provide security, transparency, service quality, and continuous maintenance of land records, with enhanced data management functionality and usability at the woreda level in an effective, spatially integrated, and sustainable manner [28]. NRLAIS is considered the key strategic component within the land administration modernization endeavor and an integral part of standardization in the country. Under this context, NRLAIS forms the framework and defines the role of stakeholders and their relationship among personnel, technology, and standard procedures. It also serves as a legitimate bearer of land information including the socio-spatial aspects of landholdings and users' interests in land and natural resources.

\section{Theoretical Base}

The theoretical base of this study is the DeLone and McLean Information System success model (D\&M IS success model) of 2003 and the theory of technology acceptance model (TAM) of Davis and modified by Venkatesh et al. [45-48]. An information system (IS) is developed using information technology (IT) to enhance the performance of individuals and organizations. However, the adoption of an IS is influenced by people, the organization, and other environmental factors [49]. Measurement of information system success is both complex and elusive [50]. Knowledge advancement in IT and related practices currently verifies that the right practice is the main factor of technology and knowledge success regarding diffusion and assimilation of IT innovations [17,51]. Researchers have derived several models to explain what makes some IS successful. For instance, Davis adapted the theory of planned behavior (TPB) and developed the technology acceptance model (TAM), which explains why some IS are more accepted by users than others [52,53]. Acceptance, however, is not equivalent to success, although acceptance of an information system is a necessary precondition to success [49]. In recent years, intention-based models were one important lines of research that employed behavioral intention to predict usage [46]. In turn, this focuses on the identification of the determinants of intention, such as attitudes, social influences, and facilitating conditions [54]. 
Since its invention, the D\&M IS success model and the TAM model have been applied across several IS domain research contexts but are rare in the LRIS context $[55,56]$. DeLone and MacLean reviewed the existing definitions of IS success and their corresponding measures and classified them into six major categories [57]. Thus, they created a multidimensional measuring model with interdependencies between the different success categories $[48,58,59]$. Ten years after the publication of their first model, DeLone and McLean [60] proposed an updated IS success model based on the evaluation of many other contributions to it. The updated D\&M IS success models of 2003 consist of six interrelated dimensions that include (1) system quality, (2) information quality, (3) intention to use, (4) user satisfaction, (5) individual impact, and (6) organizational impact [49]. Each of these variables is a composite of numerous and diverse constructs and measures. The practical application of the D\&M model is naturally dependent on the organizational context $[49,60]$.

On the other hand, TAM is an adaptation of the TPB to the field of IS. TAM later advanced to TAM 2, which incorporated additional theoretical constructs spanning social influence processes (SIP) and cognitive instrumental processes [61]. TAM posits that perceived usefulness and perceived ease of use determine an individual intention to use an IS, while the intention to use serves as a mediator of the actual use of a system. Perceived usefulness is also seen as being directly impacted by perceived ease of use $[45,47]$. Both TAM and TPB have strong behavioral elements, which assume that when someone forms an intention to act, they will be free to act without limitations. In practice, constraints such as limited ability, time, environmental or organizational limits, and unconscious habits will limit the freedom to act [49].

However, much of the existing theory in related research areas has not been articulated in a manner that lends it to rigorous testing to land tenure IS [62]. For instance, after more than a decade of modeling and building international consensus, the land administration domain model (LADM) only became a formal international standard(ISO 19152) in 2012 [15]. LADM offers a very generic spatial representation model, and it is becoming a common language in establishing geospatial referenced cadastral and land information systems $[1,13,15,63]$. On the other hand, a recent study by Biraro et al. [13] summarizes parameters and indicators to be taken to account when updating a LIS in the context of the land administration domain. In addition, Bennett et al. [1] systematically reviewed land administration system maintenance and indicated pathways for future research. Although all these models have different approaches, they have commonality in that they provide variables to be considered while evaluating or investigating a LIS development, implementation, and maintenance. This helps the authors to develop the proposed research model and empirically test it to gauge the acceptance and actual use of NRLAIS and predict its operational success in Ethiopia.

Accordingly, six latent variables identified include system quality, information quality, service quality, perceived ease of use, perceived usefulness, and intention to use as a latent construct to determine acceptance and actual use of NRLAIS. The actual use behavior of the woreda land administration experts is considered a proxy predictor of NRLAIS operational success. First, the authors posit that the land administration experts at the woreda level, as internal system end-users/operators, need to accept NRLAIS. However, acceptance alone is not enough for continued use. In addition, as part of the service quality measure, the NRLAIS requires continuous maintenance of the system infrastructure and updating of the land records. In addition, the staff needs continuous competency and skill upgrading as a critical element of the system to operate and render land administration services on a daily basis. This will be explored through the identification by land administration staff of the perceived factors that determine the acceptance and actual use of NRLAIS as a proxy predictor to its operational success.

The land administration experts at the woreda land administration offices are taken as a unit of analysis for this study, because they are the key players and responsible for daily business service delivery. NRLAIS is the main and reliable source of information of the land administration experts for decision-making for service delivery per organizational 
rules and standards. The woreda land administration experts are the most experienced in creating, describing, defining, and altering the human to parcels of land relationship to legal interests (rights, restrictions, and responsibilities). Hence, the acceptance and actual use of NRLAIS at the woreda land administration offices would have the utmost policy and operational relevance for the success and sustainability of the land administration system in the country.

On this basis, this study proposed the definition of the identified variable constructs, their measurement, and their hypothetical relationships to each variable, which are presented as follows.

System Quality (SYQU)-System quality relies on user needs and overall performance, as perceived by users [49] and as specified in the system technical requirements and development. System quality measures the technical success aspects of NRLAIS. Highlevel system quality would serve users with useful perception for doing their daily business effectively and under a secured condition that is easy to use and learn. Hence, the main measurement items identified are ease of use, usefulness, and ease of learning [49]. Thus, the following is hypothesized.

Hypothesis 1 (H1). System quality has a positive and significant influence on actual use of NRLAIS (a) on service quality, (b) on information quality, and (c) on perceived ease of use of NRLAIS.

Information Quality (INQU)-INQU is the desirable characteristics of the system outputs, such as outcome reports [60]. All types of generation of information by application of information technology cannot be used for decision making. The INQU represents the success of a land registration information system (LRIS) as the information aid to make appropriate business decisions. Seven attributes are identified, of which five are considered in this study, including availability, usability, accuracy, relevance, understandability, format, and ease of access or retrieval [49]. Information quality is often a dimension of end-user satisfaction instruments. INQU is measured as a component of user satisfaction, since it is often not distinguished as a unique construct. While this holds true, the authors contend and rather support the 2003 modified D\&M success model construct, which embedded information quality as an independent construct. Hence, the following is hypothesized.

Hypothesis 2 (H2). Information quality has a positive and significant influence on actual use of NRLAIS (a) on perceived usefulness and $(b)$ on perceived ease of use of NRLAIS.

Service Quality (SRQU)-According to Petter et al. [49], service quality refers to the quality of the institutional support that system users receive from the IS department and support personnel. Hence, service quality is considered an important organizational dimension that determines individual performance. A specific service quality improvement depends on the status of the measurable service quality attributes, which include five dimensions - tangibles, reliability, responsiveness, assurance, and empathy [64,65]. Similarly, in this study, the SRQU measures are an internal service provider dimension and are rendered to the woreda NRLAIS users by regional and federal land institutions. The measurement attributes include reliability, availability or assurance, and empathy of support staff. Reliability includes the ability to perform the promised service dependably and accurately. Assurance includes the knowledge and courtesy of an IT (technical) and operational support staff and their ability to inspire trust and confidence to the woreda land administration experts. Empathy, on the other hand, includes the caring and individualized attention the IT and support staff provides its woreda land administration experts. In addition, SRQU significantly affects information quality, perceived ease of use, perceived usefulness, and intention to use. Hence, the following is hypothesized.

Hypothesis 3 (H3). Service quality has a positive and significant influence on actual use of NRALIS (a) on perceived ease of use, (b) on information quality, and (c) on perceived usefulness of NRLAIS. 
Perceived Ease of Use (PEOU)-The extent to which individuals believe that using part of a system does not require much effort is known as perceived ease of use [47]. TAM is considered a flexible model, as it includes variables that explain technology acceptance. Perceived ease of use has a direct impact on behavioral intention and on perceived usefulness [45]. Hence, the following is hypothesized.

Hypothesis 4 (H4). Perceived ease of use has a positive and significant effect on actual use of NRLAIS (a) on perceived usefulness of NRLAIS.

Perceived Usefulness-Davis [47] proposed that certain factors such as perceived usefulness, attitude, and perceived ease of use can be the components of TAM. TAM defines individual positive or negative reactions towards a certain thing, which are referred to as attitudes. However, the perspectives of individuals of a certain system being useful to them through influencing their performance are called perceived usefulness [49]. Innovative technologies' acceptance or adoption can be determined and explained by perceived usefulness. TAM further discovered usefulness as one of the noteworthy perceptions leading to intention to adopt new systems. TAM contends that actual system use is an indicator of IS success and is associated with the ultimate impact rendered from IS [49,66]. Hence, in this study, PRUS and PEOU represent the perceived behavior of the woreda land administration experts towards acceptance and actual use of the system for the daily operational success of NRLAIS.

Hence, the following was hypothesized.

Hypothesis 5 (H5). Perceived usefulness has a positive and significant effect on actual use of NRLAIS.

System Actual Use (SYAU)-Petter et al. [49] reviewed the updated DeLone and McLean 2003 IS success model and added service quality as a new dimension, grouping all "impact" measures into a single "net benefit" [49]. The construction of "system actual use" and "intent to use" are still considered in this model as an important measure. Hence, the authors considered system actual use (SYAU) in the proposed research model. The research model is graphically represented in Figure 1 below.

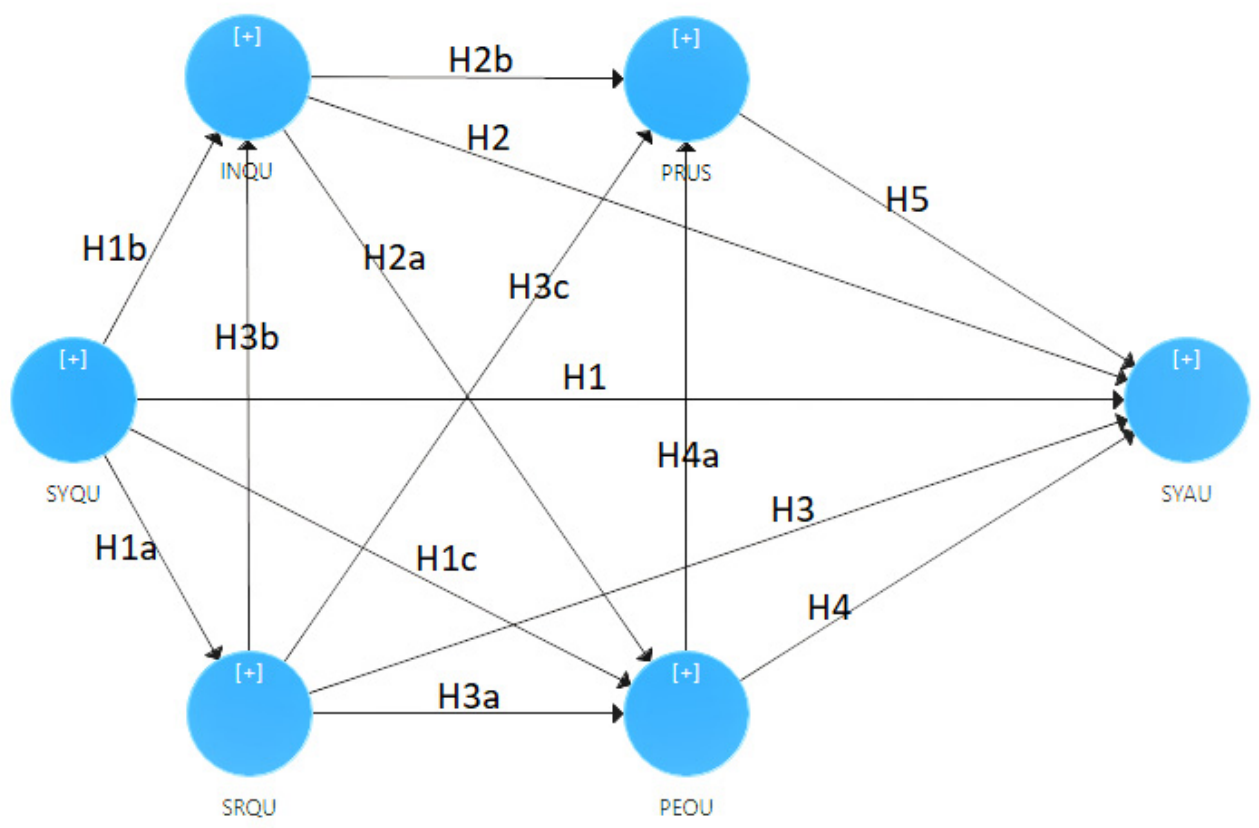

Figure 1. Research model with latent variables and hypotheses construct adapted from information system success model and technology acceptance model. 


\section{Materials and Methods}

The paper draws on primary and secondary data. The primary data were collected from the woreda land administration experts through surveys and key informant interviews of national-level senior experts. Key informant interviews were also employed to collect information on NRLAIS development, support and maintenance services, and operational deployment at the federal and regional land institutions. In addition, the secondary data were collected through a review of scientific literature and policy and program documents.

A partial least square structural equation model (PLS-SEM) was used for the data analysis, which integrates several different multivariate techniques into one model-fitting framework. Smart-PLS software version 3.0 was used to process the data analysis related to the coefficient of interaction terms. PLS-SEM includes confirmatory factor analysis, path analysis and partial least square to impute relationships between latent variables [67]. SEM was used to test the structural relationships between the 14 hypotheses and the actual use of NRLAIS. Cronbach Alpha analysis was performed to examine the consistency of data, and the value of Cronbach alpha should be greater than 0.7. SEM combines the usage of latent (unobserved) variables that represent the concept of theory and data from measures (indicators or manifest variables). The manifest variables are used as input for statistical analysis that provides evidence about relationships among latent variables. Descriptive statistics are also employed to analyze the results of survey data. Figures, tables, and maps are mainly utilized to present the results and findings of the study.

Questionnaires were formulated to collect the professional perceptions and experience of the woreda land administration experts on the technological (SYQU), organizational (INQU and SRQU), and behavioral aspects (PEOU and PRUS) of NRLAIS. The survey consists of three main sections. The first section comprises ten questions on the demographics of the woreda land administration experts. The second section consists of five questions on the NRLAIS use experience of the experts. The third section includes 29 questions related to the measurement variables and their respective indicator items. All the measurement variable indicators are formative and adapted from various earlier related studies $[49,55]$. The respondents were asked to state their opinions using a seven-point Likert scale from strongly disagree (1) to strongly agree (7).

Five to six items were initially formulated to develop pilot survey questionnaires for direct measures. The formulation of these pilot questionnaires aimed to assess each of the theory's major constructs: system quality, service quality, information quality, perceived ease of use, perceived usefulness, intention to use, and actual use behavior. Seven-point bipolar adjective scales were employed. The pilot questionnaires also included measures of background factors and other variables, including demographic characteristics, professional experience, and system use. The pilot questionnaires were distributed to 30 land administration experts convened in a national workshop in February 2021. The experts came from national and regional level land administration institutions that had been supporting the roll-out of NRLAIS at the woreda land administration offices. The results of the pilot questionnaires also allowed the authors to evaluate the validity and consistency of each item and utility of the background measures. Based on these inputs, necessary adjustment was made, and the standard questionnaires to be used in the main study were produced.

\subsection{Study Site}

The study covers 50 sample woredas of three regional states (Amhara, Oromia, and SNNP) in Ethiopia. These three regional states hold over 80 percent of the total population and close to half of the country's landmass [68]. Geographically, most of the study areas are located in the central highlands of the country and some along the south-central parts of the Rift Valley, characterized by high population density and diverse land uses. The male $(50.1 \%)$ population is slightly higher than the female $(49.9 \%)$. Over $70 \%$ of the population in the study areas is under age 30 , which aligns with the overall national age 
breakdown [68], showing a high density of younger people in the study areas. Agriculture, forestry, and livestock raising contributed directly or indirectly to the livelihoods of most of the population in the study areas. Climate change is leading to above average temperatures and greater rainfall variability, with a pronounced effect on agricultural productivity and the suitability of major crops in the study areas [32].

According to official figures from the Ethiopian Central Statistics Agency (CSA), the urbanization rate is growing at an average rate of 5.2 percent per year since 2018. If these trends continue, the urban population is projected to reach 50 million by 2034 [69]. Natural increase rather than rural-to-urban migration was the main driver of urban population growth up to 2018, with rural-to-urban migration being the main driver since 2018 [70]. As population density increases, combined with continued land fragmentation, large cohorts of young people will increasingly become functionally landless. This fuels intense land use competitions and conversions of rural land to built environments. This is becoming a serious land governance issue, particularly in the urban-rural frontiers of most Ethiopian cities [71]. Currently, access to land continues to be difficult due to increasing land scarcity and the total area of landholding per household diminishing over time in the study areas [72]. The average number of rural land parcels per study woreda is 83,000 . The woreda land administration offices had an average annual subsequent land transactions turnover of 1 percent, mainly through inheritance, donation, and land rentals. The average size of parcels involved in these transactions was about a quarter of a hectare [43].

According to the MoA [43], as of November 2021, over 180 woredas had established NRLAIS and made it operational. Woredas with operational NRLAIS are found in Amhara (61 woredas), Oromia (68 woredas), and SNNP (56 woredas) regional states (see Figure 2 for a map of the study woredas). The study excluded the inaccessible Tigray regional state due to the ongoing armed conflict and instability. According to the same source, information of about 11 million parcels has been registered in NRLAIS, covering close to 6 million hectares.

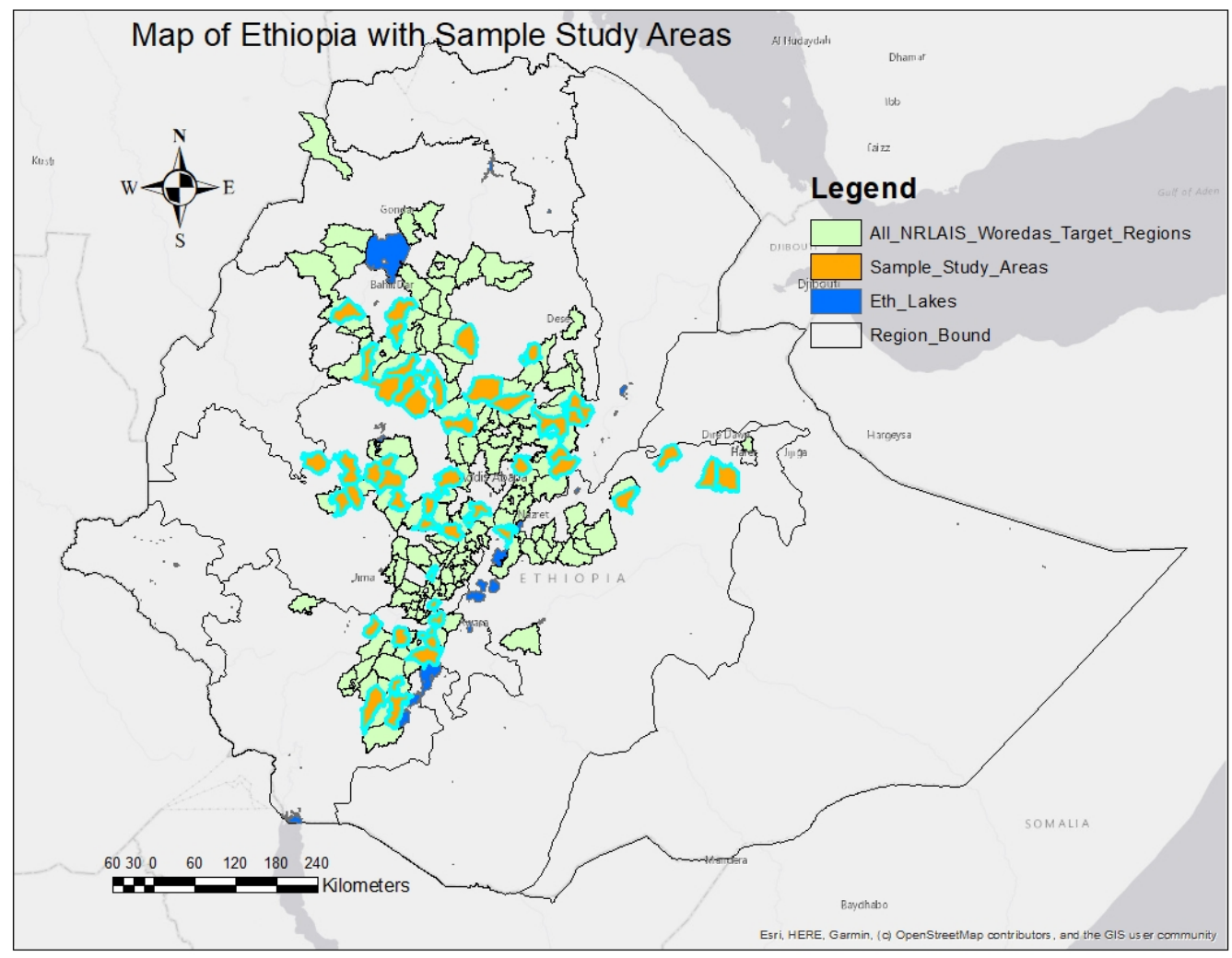

Figure 2. Study Site Map. Data Source: Ministry of Agriculture, November 2021. 


\subsection{Sampling Method}

To determine the sample size required for a study that uses a structural equation model (SEM), the authors applied the Soper [73] online free statistic calculator, which calculates prior sample sizes for structural equation models. This sampling calculator considers the number of observed and latent variables in the model, the anticipated effect size, and the desired probability and statistical power levels. Accordingly, the model of this study contains 29 observed variables and six construct latent variables. The model considers the anticipated effect size of medium (0.3), the desired probability level of 0.05 , and desired statistical power level of variables of 0.8 . Hence, the minimum initial sample size to detect effect was determined to be 161 , the minimum sample size for the model structure was 100 , and the recommended minimum sample size was 161 . The random selection process was stratified by regions in proportion to each region's number of woredas covered with operational NRLAIS.

\subsection{Sample Size}

As a result of these sample size requirements, 50 woredas were selected randomly (17 from Amhara, 18 from Oromia, and 15 from SNNP). There are four to six land administration experts per woreda on average who operate the NRLAIS, which means about 450 experts in total. In this study, land administration expert is used as a common name for people working on land administration matters in the woreda land administration offices with different titles, including land registration experts, cadastral surveyors, geospatial and land information management experts, land law and compliant management experts, land transaction experts, team leaders, etc.

From the 50 sampled woredas, about 275 land administration experts were targeted and invited to respond to the self-administered quantitative survey questionnaire by email and the Telegram social media platform. The survey data collection was conducted between April and May 2021. This virtual method of data collection was preferred due to restrictions on movement to field sites caused by the COVID-19 pandemic outbreak and the state of emergency in some of the study areas following social instabilities, particularly in the northern parts of the country. Telephone follow-up calls were also employed to clarify question items to respondents and enhance the quality of the survey data. Of the 220 filled and returned questionnaires, 19 were incomplete. The result shows a $73 \%$ success rate of properly completed questionnaires. Depending on the study design model selected, the sample and effect size of the survey data were found satisfactory.

\section{Results}

\subsection{Characteristics of Respondents}

The sample respondents included 157 (78\%) males and 44 (22\%) females (Figure 3). Despite their low numbers, the presence of women land administration professionals in the woreda land administration offices would help the policy reform move towards gender-sensitive land tenure security. About 188 (87\%) of the respondents were between 21 and 40 years of age. In addition, $82 \%$ and $18 \%$ had completed their bachelor's degrees and diplomas, respectively. This also indicates that the woreda land administration offices are filled with relatively young and degreed land administration professionals. This would likely foster innovative technology acceptance in the rural land administration sector and facilitate the establishment of the NRLAIS at woreda level. The range of disciplines the university graduates had studied were very broad, including surveying $(17 \%)$, ICT and computer science $(16 \%)$, agriculture $(14 \%)$, natural resource management $(14 \%)$, geography $(12 \%)$, land administration ( $8 \%)$, economics $(7 \%)$, and others $(13 \%)$. The diversity of the disciplines would also reflect the multi-disciplinary nature of the land administration domain. However, the number of existing land administration professionals with land law and economics backgrounds appeared low. 


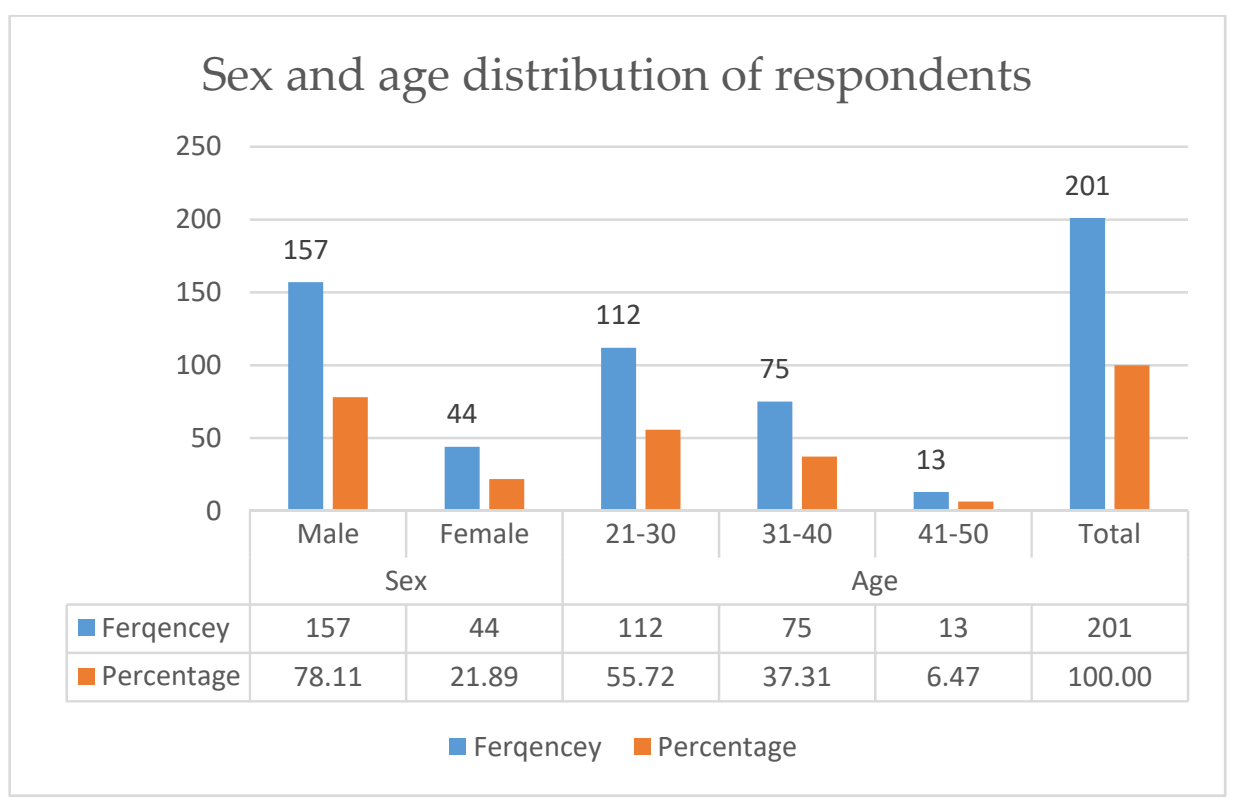

Figure 3. Sex and age distribution of respondents.

In terms of work experience, respondents were asked how long they had been working for their respective woreda land administration offices. The experience levels ranged from less than a year $(8 \%)$, to between one and seven years $(70 \%)$, to over seven years $(22 \%)$. The result revealed that about $61 \%$ of the respondents had worked for over 5 years, while $25 \%$ had worked for between 3 and 5 years. Only $24 \%$ of the respondents had worked less than 3 years in their respective woreda land administration offices. During data collection, on average, $83 \%$ of the land administration expert positions were filled. Despite frequent staff turnover reported during the key informant interviews as a key challenge for NRLAIS deployment, the survey result revealed a substantial level of staff retention in the woreda land administration offices. However, this does not mean that the reported land administration experts' turnover did not affect NRLAIS roll-out and activation.

In terms of system use, $67.2 \%$ of the respondents had NRLAIS use experience between six months and one year. In addition, $26.2 \%$ of the respondents had used NRLAIS for over one year and less than two years. Only $1.5 \%$ of the respondents had used NRLAIS for over three years, which probably indicates respondents from the pilot woreda of NRLAIS (Figure 4). This system use experience revealed that all respondents have had adequate familiarity with NRLAIS functional and operational issues.

Respondents were also asked how many minutes or hours per day they spent working on NRLAIS to discharge their service delivery related to land transaction management. As presented in Figure 5, 47\% of the respondents spent between six to eight hours. Moreover, $31 \%$ of the respondents spent between four to six hours of office hours using NRLAIS to process land transaction management and service delivery. This indicates that about $78 \%$ of respondents use NRLAIS for over half of typical office hours. In addition, this shows that NRLAIS is being used as a source and maintains land record information at woreda land administration offices.

Similarly, the respondents were asked how many times a day on average they log into the system. The question measures the frequency of system login as a proxy indicator of access security awareness and rule compliance. The survey shows that about $45 \%$ of respondents answered that they log in over ten times per workday. About $30 \%$ of respondents $\log$ in between six and ten times per workday. Only $2 \%$ of respondents $\log$ in once per day and process the land transaction management tasks assigned to them on the system. This result seems congruent with the average number of land transactions processed (5 to 13 per day) at the woreda land administration offices. This, in turn, implied relatively good compliance with standard producers and rules by the woreda 
land administration offices. However, the $2 \%$ of responses indicating only one log in per day seemed to reflect a misunderstanding of the question, as NRLAIS has a session time-out functionality.

\section{NRLAIS actual use experience in number of years}

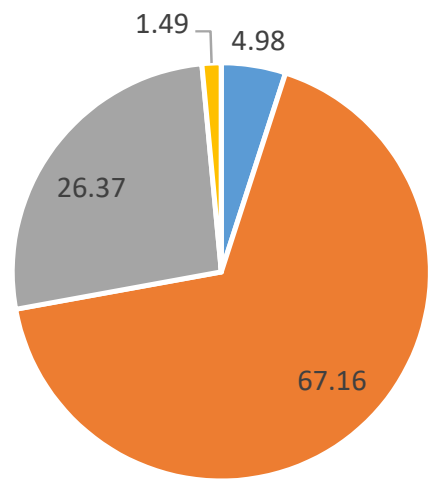

$$
\begin{array}{ll}
\text { - Less than } 6 \text { months } & =\text { Between } 6 \text { and } 11 \text { months } \\
=\text { Between } 1 \text { and } 2 \text { years } & =\text { Over } 2 \text { years }
\end{array}
$$

Figure 4. Experience of the respondents' actual usage of the NRLAIS in their daily official business discharge.

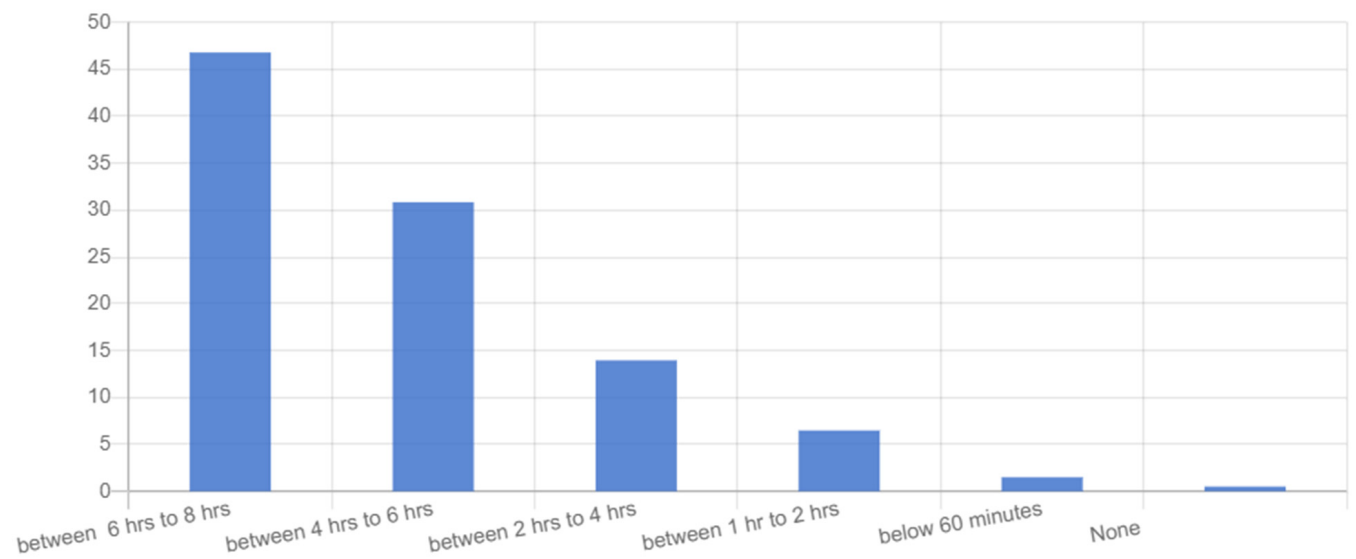

Figure 5. Time spent to process land transaction management and service delivery using NRLAIS.

According to the technical specification of NRLAIS, user-specific roles and user administration have been defined through the business processes. NRLAIS also supports user role definition, assignment, auditing, and reporting with separate management trees according to the administrative structure (federal, region, zone, and woreda) and within the same hierarchy of the woreda land administration offices [74]. To this end, respondents were asked which access privileges they were assigned as internal system users or operators. As presented in Figure 6, the respondents answered that about $44 \%$ held an expert role, $31 \%$ an officer role, $21 \%$ a supervisor role, and $3 \%$ a system administrator specific role. However, the 3\% responses most likely misunderstand the question, since system administration specific roles are assigned at federal, regional, and sometimes zonal or mobile IT support teams only. 


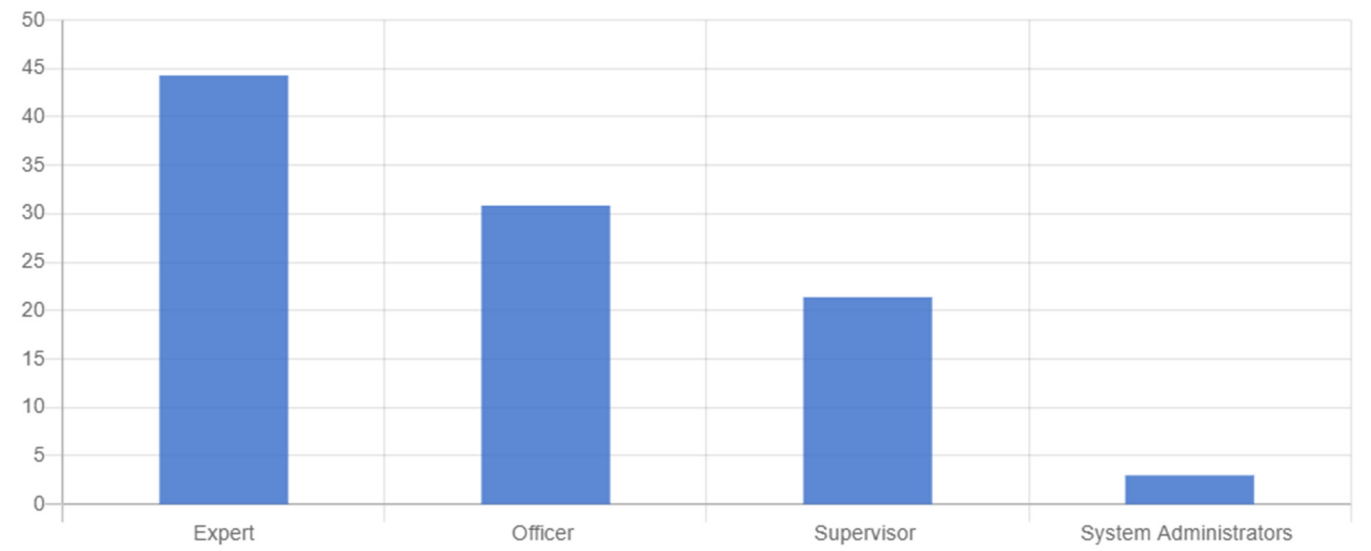

Figure 6. Users' specific assigned role of respondents.

Similarly, according to the architecture design of NRLAIS, the woreda is the primary level at which the system functions. The technical requirement also specifies five subsystems at the woreda level, which affect only parts of the system while processing transactions management, including web information, cadastral maintenance, property registration, document management, and process subsystems [28]. The processing subsystem handles the main operations to register rights, while the cadaster maintenance subsystem handles the management of spatial features (parcels, maps, points, boundaries, etc.). Both the document management subsystem and the processing subsystem have been customized for specific rural land registration processes. Respondents were asked which subsystems they have been using the most while processing land transaction management and service delivery in priority orders. The result revealed that all respondents were used the web information subsystem, as this is the user interface to log in to access the other subsystems. This is followed by the property registration subsystem $(48 \%)$, cadastral maintenance subsystem (35\%), and process subsystem and document management subsystems (17\%).

\subsection{Validity and Reliability}

The first test conducted in this study was testing the validity and reliability of the outer model. The outer model testing was performed through a process of algorithm iteration, a parameter of measurement model that includes convergence validity, discriminant validity, composite reliability, and Cronbach's alpha. Validity and reliability ensure that the multiple indications of each latent variable in the measurement model converge to measure a single construct and hence develop legitimacy, defined as the level to which things used to measure can calculate the idea they meant to quantify [75]. All items used to measure the construct should pile essentially to their constructs rather than different builds. As for the component analysis, it ensures that items are designated to their constructs, as they express high loading on them that stands out from several constructs [76]. The measurement model assessment of vertical collinearity is presented in Table 1. This shows the subjective independence of every indicator on its latent variable using cross-loading criteria.

The individual item reliability was evaluated by examining the loading and crossloadings of indicators on their respective construct. According to Fornell and Larcker's criteria [77], a reliability score of Cronbach alpha 0.6 is considered minimally acceptable, with 0.70 preferred (50\% of the explained variance). The theory also recommends that an indicator loading having a value of less than 0.40 should be removed from the model. Hence, this study found three indicator items with less than or equal to 0.4 outer loading. As per the rules, the indicator items removed from the model include INQU4 (format), PEOU4 (clear and understandable), and SYQU4 (risk of losing data). 
Table 1. Indicator item cross loading.

\begin{tabular}{|c|c|c|c|c|c|c|c|}
\hline Variables & Code & INQU & PEOU & PRUS & SRQU & SYAU & SYQU \\
\hline \multirow{4}{*}{$\begin{array}{l}\text { Information } \\
\text { Quality }\end{array}$} & INQU1 & 0.698 & 0.507 & 0.432 & 0.453 & 0.458 & 0.571 \\
\hline & INQU2 & 0.862 & 0.569 & 0.578 & 0.571 & 0.654 & 0.672 \\
\hline & INQU3 & 0.890 & 0.716 & 0.556 & 0.608 & 0.602 & 0.741 \\
\hline & INQU5 & 0.743 & 0.599 & 0.501 & 0.577 & 0.568 & 0.508 \\
\hline \multirow{4}{*}{$\begin{array}{c}\text { Perceived Ease } \\
\text { of Use }\end{array}$} & PEOU1 & 0.588 & 0.796 & 0.462 & 0.560 & 0.426 & 0.560 \\
\hline & PEOU2 & 0.608 & 0.863 & 0.578 & 0.641 & 0.507 & 0.593 \\
\hline & PEOU3 & 0.512 & 0.724 & 0.622 & 0.588 & 0.519 & 0.428 \\
\hline & PEOU5 & 0.718 & 0.867 & 0.507 & 0.699 & 0.631 & 0.626 \\
\hline \multirow{6}{*}{$\begin{array}{l}\text { Perceived } \\
\text { Usefulness }\end{array}$} & PRUS1 & 0.452 & 0.402 & 0.737 & 0.411 & 0.424 & 0.404 \\
\hline & PRUS2 & 0.412 & 0.434 & 0.680 & 0.472 & 0.340 & 0.309 \\
\hline & PRUS3 & 0.288 & 0.350 & 0.591 & 0.249 & 0.184 & 0.302 \\
\hline & PRUS4 & 0.489 & 0.483 & 0.807 & 0.432 & 0.451 & 0.441 \\
\hline & PRUS5 & 0.469 & 0.502 & 0.801 & 0.489 & 0.458 & 0.429 \\
\hline & PRUS6 & 0.640 & 0.663 & 0.773 & 0.624 & 0.576 & 0.484 \\
\hline \multirow{5}{*}{ Service Quality } & SRQU1 & 0.498 & 0.615 & 0.433 & 0.756 & 0.458 & 0.405 \\
\hline & SRQU2 & 0.371 & 0.455 & 0.322 & 0.668 & 0.266 & 0.296 \\
\hline & SRQU3 & 0.570 & 0.613 & 0.482 & 0.806 & 0.489 & 0.482 \\
\hline & SRQU4 & 0.482 & 0.553 & 0.509 & 0.730 & 0.526 & 0.422 \\
\hline & SRQU5 & 0.585 & 0.570 & 0.541 & 0.721 & 0.570 & 0.499 \\
\hline \multirow{4}{*}{$\begin{array}{c}\text { System Actual } \\
\text { Use }\end{array}$} & SYAU1 & 0.648 & 0.599 & 0.506 & 0.696 & 0.750 & 0.545 \\
\hline & SYAU2 & 0.491 & 0.502 & 0.431 & 0.398 & 0.733 & 0.465 \\
\hline & SYAU3 & 0.475 & 0.391 & 0.347 & 0.364 & 0.718 & 0.467 \\
\hline & SYAU4 & 0.417 & 0.318 & 0.375 & 0.315 & 0.725 & 0.347 \\
\hline \multirow{3}{*}{ System Quality } & SYQU1 & 0.737 & 0.643 & 0.535 & 0.551 & 0.626 & 0.843 \\
\hline & SYQU2 & 0.462 & 0.423 & 0.316 & 0.327 & 0.430 & 0.786 \\
\hline & SYQU3 & 0.662 & 0.561 & 0.449 & 0.504 & 0.477 & 0.819 \\
\hline
\end{tabular}

The composite reliability index and the average variance extracted (AVE) were applied to assess the internal consistency and convergent validity [77]. According to the rule, the square root of the AVE of a particular construct should also be greater than its correlation with other constructs. Generally, the AVE should be higher than 0.5. Table 2 shows the internal consistency of each construct. In the measurement model, the study used Cronbach's alpha and composite reliability (CR) to test the reliability of the constructs. The study found that all the CRs were higher than the recommended value of 0.700 , ranging from 0.822 to 0.887 . The Cronbach's alpha of each construct exceeded the recommended 0.700 threshold, which is 0.720 to 0.831 in the current study. Hence, convergence validity was acceptable, because the average variance extracted (AVE) was over 0.500.

Discriminant validity concerns the uniqueness of a construct, whether the phenomenon captured by a construct is unique and not reflected in the model by the other construct [75]. The subjective independence can help reduce the presence of multicollinearity amongst the latent variables, denoting that the average variance extracted (AVE) of a latent variable should be higher than the squared correlations between the latent variable and all other variables [77]. Discriminant validity was assessed by the Fornell-Larcker criterion [77]. Table 3 shows that the square-root of AVE for the construct in the diagonal 
was greater than the inner-construct correlation, which ranges from 0.732 to 0.816 . The test result of the current study may therefore imply the strong reliability of all the items.

Table 2. Reliability and Validity.

\begin{tabular}{ccccc}
\hline & $\begin{array}{c}\text { Cronbach's } \\
\text { Alpha }\end{array}$ & rho_A & $\begin{array}{c}\text { Composite } \\
\text { Reliability }\end{array}$ & $\begin{array}{c}\text { Average Variance } \\
\text { Extracted (AVE) }\end{array}$ \\
\hline INQU & 0.811 & 0.827 & 0.877 & 0.644 \\
\hline PEOU & 0.829 & 0.837 & 0.887 & 0.664 \\
\hline PRUS & 0.831 & 0.856 & 0.875 & 0.541 \\
\hline SRQU & 0.791 & 0.799 & 0.856 & 0.544 \\
\hline SYAU & 0.720 & 0.730 & 0.822 & 0.535 \\
\hline SYQU & 0.754 & 0.776 & 0.857 & 0.666 \\
\hline
\end{tabular}

Table 3. Fornell-Larcker Criterion. Note: Value in diagonal represent the Square-root of AVE.

\begin{tabular}{ccccccc}
\hline & INQU & PEOU & PRUS & SRQU & SYAU & SYQU \\
\hline INQU & 0.802 & & & & & \\
\hline PEOU & 0.749 & 0.815 & & & & \\
\hline PRUS & 0.648 & 0.664 & 0.736 & & & \\
\hline SRQU & 0.692 & 0.767 & 0.632 & 0.737 & & \\
\hline SYAU & 0.715 & 0.645 & 0.581 & 0.644 & 0.732 & \\
\hline SYQU & 0.782 & 0.681 & 0.548 & 0.582 & 0.639 & 0.816 \\
\hline
\end{tabular}

\subsection{Structural Model (Inner Model) Analysis}

The structural model (Figure 7) reflects the path hypothesized in the research framework. Using the bootstrap resampling technique (5000 resamplings), the path coefficient was then tested to investigate the significance of the hypothesis. The $t$-value $>1.96$ is significant at $p<0.05$, and $t$-value $>2.58$ is significant at $p<0.01$ [67]. A structural model is also assessed based on the $\mathrm{R}^{2}, \mathrm{Q}^{2}$, and significance of paths. The goodness of the model is determined by the strength of each structural path, determined by the $\mathrm{R}^{2}$ value for the dependent variable; the value for $\mathrm{R}^{2}$ should be equal to or over 0.1 [67]. The values of $\mathrm{R}^{2}$ in PLS are interpreted similarly to those obtained from multiple regression analysis. It was considered that $\mathrm{R}^{2}$ values of $0.75,0.50$, and 0.25 are substantial, moderate, and weak, respectively [67], and evaluated subsequently. Hence, the predictive capability is established.

In this study, information quality accounted for 69.6 percent of the variance in explaining perceived usefulness and perceived ease of use. Meanwhile, service quality accounted for 33.9 percent of the variance explaining perceived usefulness and perceived ease of use. Likewise, perceived ease of use accounted for 69.5 percent, and perceived usefulness accounted for 51.2 percent of the variance explaining SYAU. Finally, the current model explained 57.5 of the variance in acceptance and actual use of NRLAIS, which provided substantial explanatory power and predictive capability (see Figure 7).

Furthermore, the model fit was assessed using SRMR. The value of SRMR was 0.100, equal to the required value of 0.10 , indicating acceptable model fit [78]. Further assessment of the goodness of fit hypotheses were tested to ascertain the significance of the relationship (Table 4). 


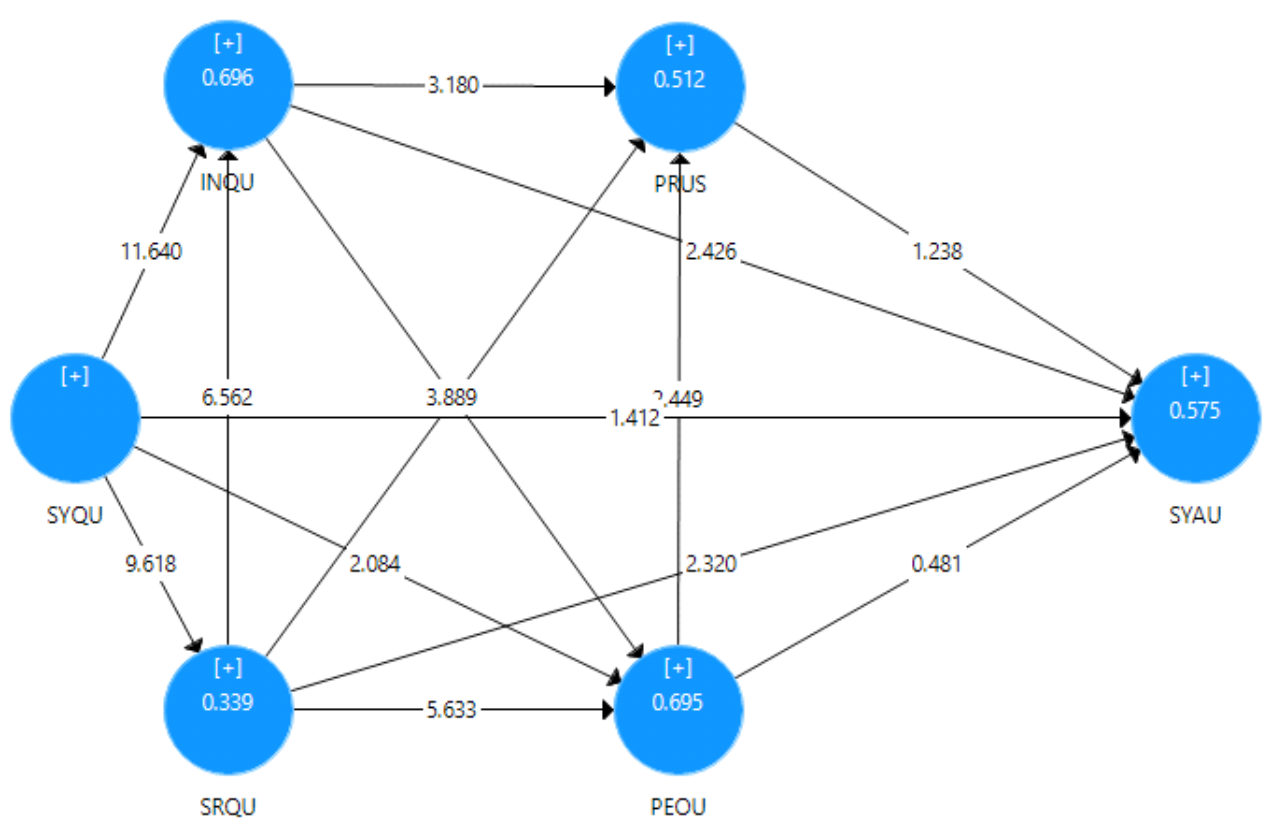

Figure 7. Measurement and structure equation model results of the research model.

Table 4. Model fit analysis of the proposed model.

\begin{tabular}{lcccccccc}
\hline & $\begin{array}{c}\text { Original } \\
\text { Sample (O) }\end{array}$ & $\begin{array}{c}\text { Sample } \\
\text { Mean (M) }\end{array}$ & $\mathbf{9 5 \%}$ & $\mathbf{9 9 \%}$ & $\begin{array}{c}\text { Original } \\
\text { Sample (O) }\end{array}$ & $\begin{array}{c}\text { Sample } \\
\text { Mean (M) }\end{array}$ & $\mathbf{9 5 \%}$ & $\mathbf{9 9 \%}$ \\
\hline Saturated Model & 0.100 & 0.059 & 0.070 & 0.074 & 3.520 & 1.241 & 1.727 & 1.944 \\
\hline Estimated Model & 0.100 & 0.060 & 0.072 & 0.075 & 3.521 & 1.298 & 1.808 & 1.963 \\
\hline
\end{tabular}

The studied 5000 resamples also generate $95 \%$ confidence intervals, and hypotheses testing results are summarized in Table 5 . A confidence interval not equal to zero indicates a significant relationship. Further, $\mathrm{Q}^{2}$ establishes the predictive relevance of the endogenous constructs. A $\mathrm{Q}^{2}$ above 0 shows that the model has predictive relevance. The result shows that there is significance in the prediction of the construct in the research model. Therefore, except for $\mathrm{H} 4$ and $\mathrm{H} 5$, the rest of the hypotheses have positive and significant impact on the acceptance, which is a proxy predictor to NRLAIS operational success.

H1 evaluates whether SYQU has a positive and significant effect on the acceptance and SYAU of NRLAIS. The result revealed that a positive and significant impact on SYAU ( $\beta=0.639, t=10.019, p=0.000)$, on the SRQU (H1a: $\beta=0.583, t=9.879, p=0.000)$, on INQU (H1b: $\beta=0.583, t=9.879, p=0.000)$, and on the PEOU (H1c: $\beta=0.194, t=2.128, p=0.034$ ). Hence, H1 was fully supported. The result shows (Figure 7 and Table 5) that $63.9 \%$ of NRLAIS acceptance and actual usage was explained by the system quality variables with indicators including easy to learn (SYQU1: $84.3 \%$ ), easy to use (SYQU2: $78.6 \%$ ), and useful for doing daily business effectively under secured conditions (SYQU3: 81.9\%).

Secondly, the result shows that (Figure 7 and Table 5) information quality is found to have a positive and significant influence on acceptance and actual use of NRLAIS (H2). The result revealed that the relation between INQU and SYAU $(\beta=0.436, \mathrm{t}=3.600, p=0.000)$ (2a) on perceived usefulness, i.e., INQU $\rightarrow$ PRUS $(\beta=0.283, t=3.347, p=0.001)$, and ( $2 b)$ on perceived ease of use, i.e., INQU $\rightarrow$ PEOU $(\beta=0.275, t=3.818, p=0.000)$, has a positive and significant influence. Hence, $\mathrm{H} 2$ was supported. Respondents admitted that information quality of NRLAIS has a positive and significant influence on acceptance and actual use. When the information generated by NRLAIS is accurate, useable, relevant, reliable, and understandable, the woreda land administration experts consider the information system useful and valuable. This result revealed that information availability $(69.8 \%)$ is the main characteristic of NRLAIS to ensure a necessary level of acceptance for land administration 
to provide seamless services that do not halt business. In addition, information usability $(86.2 \%)$, information accuracy (89\%), information relevance, and understandability $(74.3 \%)$ are influencing factors that determine information quality.

Table 5. Mean, STDEV, T-Values, $p$-Values, $\mathrm{R}^{2}$, and $\mathrm{Q}^{2}$.

\begin{tabular}{|c|c|c|c|c|c|c|}
\hline & $\beta$ & STDEV & T Tatistics & $p$ Values & $2.50 \%$ & $97.50 \%$ \\
\hline INQU -> PEOU & 0.275 & 0.072 & 3.818 & 0.000 & 0.154 & 0.420 \\
\hline INQU -> PRUS & 0.283 & 0.085 & 3.347 & 0.001 & 0.105 & 0.427 \\
\hline INQU -> SYAU & 0.436 & 0.121 & 3.600 & 0.000 & 0.182 & 0.655 \\
\hline PEOU -> PRUS & 0.291 & 0.114 & 2.556 & 0.011 & 0.083 & 0.508 \\
\hline PEOU -> SYAU & 0.086 & 0.101 & 0.852 & 0.395 & -0.111 & 0.294 \\
\hline PRUS -> SYAU & 0.111 & 0.086 & 1.285 & 0.199 & -0.039 & 0.290 \\
\hline SRQU -> INQU & 0.356 & 0.053 & 6.681 & 0.000 & 0.246 & 0.453 \\
\hline SRQU -> PEOU & 0.465 & 0.084 & 5.537 & 0.000 & 0.285 & 0.615 \\
\hline SRQU -> PRUS & 0.213 & 0.096 & 2.222 & 0.027 & 0.022 & 0.401 \\
\hline SRQU -> SYAU & 0.208 & 0.101 & 2.057 & 0.040 & 0.027 & 0.416 \\
\hline SYQU -> INQU & 0.575 & 0.048 & 12.019 & 0.000 & 0.477 & 0.665 \\
\hline SYQU -> PEOU & 0.194 & 0.091 & 2.128 & 0.034 & -0.006 & 0.355 \\
\hline SYQU -> SRQU & 0.583 & 0.059 & 9.879 & 0.000 & 0.475 & 0.693 \\
\hline \multirow[t]{2}{*}{ SYQU -> SYAU } & 0.639 & 0.064 & 10.019 & 0.000 & 0.503 & 0.752 \\
\hline & $\mathrm{R}^{2}$ & $\mathrm{Q}^{2}$ & & & & \\
\hline INQU & 0.697 & 0.434 & & & & \\
\hline PEOU & 0.695 & 0.451 & & & & \\
\hline PRUS & 0.512 & 0.252 & & & & \\
\hline SRQU & 0.340 & 0.175 & & & & \\
\hline SYAU & 0.567 & 0.258 & & & & \\
\hline SYQU & 0.000 & & & & & \\
\hline
\end{tabular}

Thirdly, service quality has a positive and significant influence on acceptance and actual use of NRLAIS (H3) (3a) on the perceived ease of use, (3b) on the information quality, and $(3 \mathrm{c})$ on the perceived usefulness of NRLAIS. The result revealed that a positive and significant impact on SYAU ( $\beta=0.208, \mathrm{t}=2.057, p=0.040)$; (3a) on the perceived ease of use, i.e., SRQU -> PEOU ( $\beta=0.465, \mathrm{t}=5.537, p=0.000)$; $(3 \mathrm{~b})$ on the information quality, i.e., SRQU $->$ INQU $(\beta=0.575, t=12.019, p=0.000)$; and $(3 c)$ on the perceived usefulness, i.e., SRQU $\rightarrow$ PRUS $(\beta=0.213, \mathrm{t}=2.222, p=0.027)$. Hence, H3 was fully supported. The SRQU construct is one of the most influential service quality measurement instruments and is widely used in many applications, and the development of service quality affects IS success factor. The result revealed that the technical support service provided by the federal and regional land institutions is significantly affecting the acceptance and actual usage of NRLAIS at the woreda offices of land administration. The result revealed that $20.8 \%$ of the acceptance and actual use of NRLAIS were explained by the quality of support services (Figure 7). This includes the knowledge and skill transfer made through classroom training and during data migration, on-the-spot support by a mobile IT team, and remote helpdesk support. Such support services were found relevant to the job performance and awareness regarding compliance with actual system use by the woreda land administration experts.

Conversely, $\mathrm{H} 4$ evaluates whether PEOU has a positive and significant effect on SYAU of NRALIS. The result revealed that PEOU has a positive but an insignificant impact on acceptance and SYAU $(\beta=0.086, \mathrm{t}=0.852, p=0.395)$, and (4a) PEOU has a positive 
and significant effect on perceived usefulness, i.e., PEOU $\rightarrow$ PRUS $(\beta=0.291, t=2.556$, $p=0.011)$. Hence, $\mathrm{H} 4$ was not supported, while H4a was fully supported.

Similarly, H5 evaluates whether PRUS has a positive and significant effect on acceptance and SYAU of NRLAIS. The result revealed that PRUS has a positive but insignificant impact on acceptance and SYAU $(\beta=0.111, t=1.285, p=0.199)$. Hence, H5 was not supported.

\subsection{Mediation Analysis}

Mediation analysis was performed to assess the mediating (INQU, SRQU, PEOU and PRUS) role of system actual use outcomes. The results revealed an insignificant $(p>0.05)$ mediating role of PRUS (H3a: $\beta=0.024, \mathrm{t}=2.000, p=0.322$ ) and a partially significant $(p=$ 0.046 ) mediating role of PEOU (H3c: $\beta=0.040, t=2.000, p=0.046$ ). INQU was found to significantly mediate the relationship between SRQU and SYAU of NRLAIS (see Table 6).

Table 6. Total, specific, and indirect effect between the independent variables and dependent variable.

\begin{tabular}{|c|c|c|c|c|c|c|c|c|c|}
\hline & Total Effect & $\mathrm{T}$ & Sig & Direct Effect & Sig & Specific Indirect Effect & Effect & $T$ & Sig \\
\hline \multirow{3}{*}{ SR $->$ SYAU } & 0.464 & 7.397 & 0.000 & 0.208 & 0.040 & SRQU -> INQU -> SYAU & 0.251 & 3.665 & 0.000 \\
\hline & & & & & & SRQU -> PEOU -> SYAU & 0.040 & 2.000 & 0.046 \\
\hline & & & & & & SRQU -> PRUS -> SYAU & 0.024 & 2.000 & 0.322 \\
\hline
\end{tabular}

\section{Discussion}

Land administration governance in Ethiopia is complex and requires the use and integration of an innovative and robust set of land registration information technologies that meet the social, economic, and environmental goals of tenure security and service delivery. Innovative information technologies and systems can be used to help build a quicker, accessible, affordable, and more reliable LIS. This, in turn, provides landholders, communities, business firms, and the general public with a clearer sense of tenure security, particularly to women, by providing evidence of recognized and enforceable land and resource rights. Landholders with secure tenure rights will be incentivized to make longterm land-based investment that improve welfare and environmental outcomes.

This study demonstrated that the theoretical application of the research model that integrated selected variables from the IS success and TAM models to explain the acceptance and actual usage of NRLAIS in Ethiopia; acceptance and usage serve as proxy predictors of NRLAIS' operational success. The paper explored the determining factors and their relationships with technical (SYQU), organizational (SRQU and INQU), and the behavioral (PEOU and PRUS) aspects of the woreda land administration experts that influence the acceptance and actual usage of NRLAIS in Ethiopia. These constructs, along with measuring the LRIS' operational success, pave the way to scientifically research land administration system digitalization, particularly in developing economies. The research suggests that the IS success model integrated with TAM with selected variables was applicable for explaining LRIS acceptance and actual usage as a proxy predictor for operational success. This study does not include the organizational net benefit in its latent variable constructs measured by productivity, competitiveness, and management improvements. The discussion of the results is presented in detail as follows.

Firstly, based on the structural model, the study examined the relationship between the system quality and acceptance and actual use of NRLAIS. The results indicate that there is a positive and significant relationship between the system quality and the acceptance and actual use of NRLAIS (H1) on SRQU (1a), on INQU (1b), and on PEOU (1c). Based on that, it can be inferred that the woreda land administration experts relate this system quality with the acceptance and actual use of NRLAIS. The system quality constructs reflect the technical aspects of NRLAIS to its acceptance and actual use. These are that it is easy to learn, easy to use, and useful to do daily business related to land transaction management and service 
delivery at the woreda land administration offices. Malik et al. [55] and Hamdan and Al-Hajra [79] observed that a system's level of association had a positive influence on the perceived ease of use and the perceived usefulness of the system under investigation $[55,56]$. Moreover, the system quality would also affect the information quality and the service quality of the organization under study, and this, in turn, affects the acceptance and actual usage of the system.

As described in the background section, the technical requirement review provides an understanding of the different components of NRLAIS as an automated and streamlined land registration information system for rural land. The functional and legal aspects of the rural land administration are key requirements of NRLAIS. This includes data capturing, data management, visualization, and workflow management and reporting. The NRLAIS system development process has engaged the regional and federal level land administration professionals in terms of the definition, verification, and approval of the functional and legal requirements as part of its quality assurance system. Hence, the multitiered application architecture makes NRLAIS possible to use at the different administrative levels with differentiated functionality and user interface. The login function and session time-out are also suited to secure the user's access to the system and the subsystems before any transaction begins. Furthermore, the classified roles of system users (officer, expert, and supervisor) represent read-only, data entry, and approval, and change secure system access as primary actors in the existing administrative roles in the institutions that operate the NRLAIS.

Regarding information quality, the results of this study are consistent with what was found by Nugroho and Chang et al. [48,80]. NRLAIS also manages information regarding land transaction performance at the woreda level, such as the type and patterns of land transactions made. Updating the land record is one of the key functions of the woreda land administration offices. This affects the efficiency and effectiveness of the land administration system and staff job performance related to all land transactions. Relevant and accurate land information affects operational business decisions of transactions to the regional governments, to federal ministries, and to the general public. Since land relationships change frequently, the information in NRLAIS needs to be updated and maintained. Timely and accurate management of information ensured through well-maintained cadastral and land use related information should reflect the reality on the ground. Complete and up-to-date land information will support expedited business decisions made by the woreda land administration offices, thereby enhancing legitimacy and trustworthiness of the woreda land administration offices. Further to this, the availability of such geospatial land information lays a foundation for the national spatial data infrastructure to flourish and be accessible to all concerned in order to inform strategic and policy reform.

Moreover, NRLAIS has a modular design that allows the system to be deployed at several administrative levels. The modular stack and the web-based server design of NRLAIS enable the transfer of data and information from lower to higher administration levels to include zone, region, and federal levels that facilitate easier deployment. However, this data and information flow is yet to happen due to low and weak telecom network infrastructure coverage in the country for access to strong bandwidth Internet services.

With regard to service quality, the result of the current study is consistent with the findings of Al Fraihat [81], Nugroho [48], and Malik et al. [55]. These studies found that the effective role or support service of the technical staff, (i.e., service quality) is positively related to the eventual use of the system [81]. Competency of the support staff, vendor support, and availability of training affected acceptance and use of IS [82]. The current study also revealed that the technical support service is significantly affecting the acceptance and actual usage of NRLAIS. However, an IT-enabled LRIS at this decentralized scale needs a solid IT management approach, which is dependable, available, and has good empathy of support staff. NRLAIS with sufficient quality affects the type and intensity of technical support in the transition operation from manual to digital service delivery. 
The quality of support service, in turn, affects adherence to standardized methods and procedures for service delivery in the acceptance and actual use of NRLAIS.

The transition and service operation is the highest priority for NRLAIS to function and be operational at the woreda level. In the context of the establishment of NRLAIS, it is essential to have a proper knowledge transfer from the developer to an in-house or outsourced local IT company, which carries out the ongoing system maintenance, upgrading, and operational support services. The woreda land administration experts knowledge and skill acquired through training, experience gained during data migration, self-practice, and helpdesk support are also critical success factors. Therefore, the support service quality should be strong, regular, dependable, and available when needed at the woreda level.

Fourthly, the analysis revealed that perceived ease of use has a positive but insignificant effect on the acceptance and actual use of NRLAIS. However, perceived ease of use has a positive and significant effect on the perceived usefulness of NRLAIS (H4a). Hence, H4 was not supported, while H4a was supported. Malik et al. [55,56] found that perceived usefulness is influenced by an understanding of the information quality; [83] the current study analysis also revealed similar findings (H2b). Machdar and Malik et al. [55,56,84] found that the quality of information positively affects perceived usefulness and ease of use, and perceived ease of use positively affects perceived usefulness [84]. Several studies have found strong relationships between perceived usefulness and self-reported use [85], extent of use [86], or dependence on an information system [87]. Empirical studies in various contexts have confirmed that the post-usage perception of usefulness has a strong association with actual use [88]. This holds true in the current study too, since the hypothetical relationships between the perceived ease of use effect on acceptance and actual use was found to be significant. This may be due to the fact that the survey collected post-usage perceptions rather than measuring intention to use prior-actual system use. Therefore, the behavioral antecedences of perceived ease of use and actual use should not be underestimated to meet operational success, though perceived ease of use has shown a weak relationship to actual use in the analysis.

The result of this study revealed that $69.5 \%$ of the acceptance and actual use of NRLAIS is explained by the perceived ease of use construct (Figure 7). The quality of information affects the perceived ease of use (27.5\%), as well as the perceived usefulness $(28.3 \%)$ of the woreda land administration experts. This, in turn, affects the acceptance and actual use of NRLAIS to maintain the land records of subsequent land transactions and to make effective and efficient business decisions in daily service delivery.

\section{Conclusions}

Investigation of the general antecedents of what causes users' acceptance and use of innovative information technology in the land administration domain is critical for digital transformation and improve service delivery. The research has attempted to understand the influencing factors of the acceptance and actual use of NRLAIS in Ethiopia to gauge and predict its operational success. The research found that, despite the fact that the NRLAIS program of Ethiopia is at the initial stage of establishment, the speed and scale of its implementation have implications for its acceptance and actual use. The authors argue that investigating what factors affect this transition is worth studying in order to document the experience and generate a knowledge base for similar initiatives in other countries.

The research demonstrated that a system must be developed that understands the functional, technical, legal, and administrative requirements. These factors significantly affect the acceptance and actual use of the system and better predict its operational success. Similarly, the organizational aspects related to support services and information quality determine the behavioral attributes of staff to accept and use NRLAIS and rely on it to make business decisions and deliver services on a daily basis.

Moreover, twelve of the fourteen constructs (hypotheses) in this study were found to be significant in terms of affecting the acceptance and actual use of NRLAIS. The findings 
rendered a theoretical and practical knowledge base about land administration information digitalization and operational success. Practically, the findings of this study help the country to make strategic and policy decisions on the planning, implementation, and use of a land registration information system for sustainable land resource management and governance systems. Secondly, the study demonstrated that, while the service quality and information quality constructs to the acceptance and actual use of NRLAIS deserve an independent construct, they are also playing a mediating role between system quality and actual use of the system. The proposed model empirically revealed strong construct validity, in that it captures multiple aspects of each variable, which is a change from much of the measurement of LIS success model constructs that focus on only one aspect of the construct.

Historically, the land administration system in Ethiopia has evolved in the urban-rural cadastral and land registration system divide. This costs the country a great deal in terms of economic, social, and environmental management and governance systems. With the depth of functional and legal requirements compliance, NRLAIS is instrumental in strengthening secure tenure rights in rural jurisdictions. It also demonstrates that standardization would pave the way for the development of a unified land administration information system in Ethiopia that embraces both urban and rural land tenure.

Despite the study's contribution to policy, research, and practice, the authors suggest that a similar future research undertaking would be recommendable in other developing countries and should include other variables that are not considered in this study. The method applied in this study adds to the knowledge base and replicability of the proposed model under the land administration information domain. Further, future studies should include the organizational net benefit in their latent variable constructs as measured by productivity, competitiveness, and management improvements. Finally, the research did not consider the success of NRLAIS from the perspective of an external system user, such as financial institutions, courts, businesses, and smallholder farmers, which would be worth studying in a future research undertaking.

Author Contributions: Conceptualization, S.A.A., F.S.W. and T.T.N.; methodology, S.A.A.; software, S.A.A.; validation, S.A.A., F.S.W. and T.T.N.; formal analysis, S.A.A.; investigation, S.A.A.; resources, S.A.A., F.S.W. and T.T.N.; data curation, S.A.A.; writing-original draft preparation, S.A.A.; writingreview and editing, S.A.A., F.S.W. and T.T.N.; visualization, S.A.A.; supervision, F.S.W. and T.T.N.; project administration, Kelly Robbins; funding acquisition, S.A.A., F.S.W. and T.T.N. All authors have read and agreed to the published version of the manuscript.

Funding: The research was supported by the Partnerships for Enhanced Engagement in Research (PEER) Program, financed by the U.S. Agency for International Development (USAID) and administered by the U.S. National Academy of Sciences (NAS) under cooperative agreement AID-OAA-A11-00012. The authors highly acknowledge and appreciate this generous financial support, without which this research could not have been realized.

Institutional Review Board Statement: All respondents of survey questionnaire and key informant interviewees are not mentioned by name. Results are aggregated and cannot be tracked back to individual person.

Informed Consent Statement: All person involved in the study participated voluntarily and agreed the study results derived from their responses.

Data Availability Statement: Not applicable.

Acknowledgments: Our heartfelt gratitude goes to Dilu Shaleka, Dean of College of Development Studies of Addis Ababa University and his finance team who have been supportive to all administrative requests. We would also like to extend our thanks to Kelly Robbins, Senior Program Officer, of the National Academies of Sciences, Engineering, and Medicine (NAS), who administers the PEER grant funds, for her unwavering support to our research work. We owe our full-hearted thanks to Yohannes Redda from Ministry of Agriculture of the Responsible and Innovative Land Administration Project (REILA II), Dawit Woldemariam from Oromia Land Administration and Use Bureau, Demisachew Agegnehu from Amhara Region Bureau of Land, and Henok Yosef from 
SNNP regional state, who have supported the data collection process. Without their close support the remote data collection would not have been successful. Our thanks also goes to all the study woreda land administration experts who set aside time to answer the research questions under an unprecedented operating context in the country due to the COVID-19 outbreak restrictions, social instability, and security conditions in the country.

Conflicts of Interest: The authors declare no conflict of interest.

\section{References}

1. Bennett, R.M.; Unger, E.M.; Lemmen, C.; Dijkstra, P. Land administration maintenance: A review of the persistent problem and emerging fit-for-purpose solutions. Land 2021, 10, 509. [CrossRef]

2. Framework for Effective Land Administration Expert Group on Land Administration and Management United Nations Committee of Experts on Global Geospatial Information Management (UN-GGIM) Content. 2020. Available online: https://ggim.un.org/meetings/GGIM-committee/10th-Session/documents/E-C.20-2020-29-Add_2-Framework-forEffective-Land-Administration.pdf (accessed on 23 September 2021).

3. Masuda, Y.J.; Kelly, A.C.; Robinson, B.E.; Holland, M.B.; Bedford, C.; Childress, M.; Game, E.T.; Ginsburg, C.; Hilhorst, T.; Lawry, S.W.; et al. How do practitioners characterize land tenure security? Conserv. Sci. Pract. 2020, 2, e186. [CrossRef]

4. Byamugisha, F.F.K. Experiences and development impacts of securing land rights at scale in developing countries: Case studies of China and Vietnam. Land 2021, 10, 176. [CrossRef]

5. Mitchell, D.; Barth, B.; Ho, S.; Sait, M.S.; McEvoy, D. The benefits of fit-for-purpose land administration for urban community resilience in a time of climate change and COVID-19 pandemic. Land 2021, 10, 563. [CrossRef]

6. Singirankabo, U.A.; Ertsen, M.W. Relations between land tenure security and agricultural productivity: Exploring the effect of land registration. Land 2020, 9, 138. [CrossRef]

7. Krigsholm, P.; Riekkinen, K.; Ståhle, P. The changing uses of cadastral information: A user-driven case study. Land 2018, 7, 83. [CrossRef]

8. McLain, R.; Lawry, S.; Guariguata, M.R.; Reed, J. Toward a tenure-responsive approach to forest landscape restoration: A proposed tenure diagnostic for assessing restoration opportunities. Land Use Policy 2021, 104, 103748. [CrossRef]

9. Lawry, S.; Samii, C.; Hall, R.; Leopold, A.; Hornby, D.; Mtero, F. The impact of land property rights interventions on investment and agricultural productivity in developing countries: A systematic review. J. Dev. Eff. 2017, 9, 61-81. [CrossRef]

10. Schwartz, M.W.; Cook, C.N.; Pressey, R.L.; Pullin, A.S.; Runge, M.C.; Salafsky, N.; Sutherland, W.J.; Williamson, M.A. Decision Support Frameworks and Tools for Conservation. Conserv. Lett. 2018, 11, e12385. [CrossRef]

11. Ingram, G.K.; Hong, Y. Property Rights and Land Policies; Lincoln Institute of Land Policy: Cambridge, MA, USA, 2009; ISBN 9781558441880.

12. Jing, Y.; Bennett, R.; Zevenbergen, J. Up-to-dateness in land administration: Setting the record straight. Coordinates 2014, 10, 37-42.

13. Biraro, M.; Zevenbergen, J.; Alemie, B.K. Good practices in updating land information systems that used unconventional approaches in systematic land registration. Land 2021, 10, 437. [CrossRef]

14. Aydinoglu, A.C.; Bovkir, R. Generic land registry and cadastre data model supporting interoperability based on international standards for Turkey. Land Use Policy 2017, 68, 59-71. [CrossRef]

15. Unger, E.M.; Bennett, R.M.; Lemmen, C.; Zevenbergen, J. LADM for sustainable development: An exploratory study on the application of domain-specific data models to support the SDGs. Land Use Policy 2021, 108, 105499. [CrossRef]

16. UN-GGIM. Framework for Effective Land Administration A Reference for Developing, Reforming, Renewing, Strengthening or Modernizing Land Administration and Management Systems Expert Group on Land Administration and Management United Nations Committee of Experts on Global Geospatial Information Management (UN-GGIM). 2019. Available online: https: //ggim.un.org/meetings/GGIM-committee/9th-Session/documents/E_C.20_2020_10_Add_1_LAM_background.pdf. (accessed on 20 January 2021).

17. Zeng, Z.; Cleon, C.B. Factors affecting the adoption of a land information system: An empirical analysis in Liberia. Land Use Policy 2018, 73, 353-362. [CrossRef]

18. Bolwig, S.; Cold-Ravnkilde, S.M.; Rasmussen, K. Achieving Sustainable Natural Resource Management in the Sahel after the Era of Desertification Markets, Property Rights, Decentralisation and Climate Change; Danish Institute for International Studies: København, Denmark, 2009; ISBN 9788776053086.

19. Byamugisha, F. Securing Land Tenure and Easing Access to Land; African Center for Economic Transformation: Accra, Ghana, 2016.

20. Peters, P.E. Challenges in Land Tenure and Land Reform in Africa: An Anthropological Perspective; CID Working Paper No. 141; Center for International Development at Harvard University: Cambridge, MA, USA, 2007.

21. Byamugisha, F.F.K. Agricultural Land Redistribution and Land Administration in Sub-Saharan Africa: Case Studies of Recent Reforms; Direction in Development Agriculture and Rural Development; World Bank: Washington, DC, USA, 2014.

22. Simbizi, M.C.D.; Bennett, R.M.; Zevenbergen, J. Land tenure security: Revisiting and refining the concept for Sub-Saharan Africa's rural poor. Land Use Policy 2014, 36, 231-238. [CrossRef]

23. Enemark, S.; Mclaren, R.; Lemmen, C.; Antonio, D.; Gitau, J.; De Zeeuw, K.; Dijkstra, P.; Quinlan, V.; Freccia, S. Fit-For-Purpose Land Administration: Guiding Principles for Country Implementation; Global Land Tool Network: Nairobi, Kenya, 2016. 
24. Zevenbergen, J.; Augustinus, C.; Antonio, D.; Bennett, R. Pro-poor land administration: Principles for recording the land rights of the underrepresented. Land Use Policy 2013, 31, 595-604. [CrossRef]

25. Mitchell, D.P.; Zevenbergen, J.A. Toward Land Administration Systems to Support Climate Change Mitigation Payments. Land Tenure J. 2011, pp. 57-79. Available online: http://www.fao.org/nr/tenure/land-tenure-journal/index.php/LTJ/article/view/33. (accessed on 23 September 2021).

26. James, K.; Geosystems, L. Improving Rwanda Land Administration Information Systems. Geomat. Indaba 2016-Stream 2016, 1.

27. Cochrane, L.; Hadis, S. Functionality of the land certification program in Ethiopia: Exploratory evaluation of the processes of updating certificates. Land 2019, 8, 149. [CrossRef]

28. Ministry of Agriculture. Upgraded Information System/IT Strategy for National Rural Land Administration Information System (NRLAIS), 2017-2021. Federal Democratic Republic of Ethiopia Ministry of Agriculture and Natural Resources, Rural Land Administration and Use Directorate Supported by Ministry for Foreign Affairs of Finland; Responsible and Innovative Land Administration in Ethiopia (REILA II): Addis Ababa, Ethiopia, 2017.

29. Wubie, A.M.; de Vries, W.T.; Alemie, B.K. Synthesizing the dilemmas and prospects for a peri-urban land use management framework: Evidence from Ethiopia. Land Use Policy 2021, 100, 105122. [CrossRef]

30. Lemmen, C.; Zevenbergen, J.; Lengoiboni, M.; Deininger, K.; States, U.; Burns, T. First experiences with High Resolution Imagery Based Adjudication Approach for Social Tenure Domain Model in Ethiopia. In Proceedings of the FIG-World Bank Conference: Land Governance in Support of the Millennium Development Goals, Responding to New Challenges, Washington, DC, USA, 9-10 March 2009.

31. Bruce, J.W.; Hoben, A.; Rahmato, D. After the Derg: An Assessment of Rural Land Tenure Issues in Ethiopia; Land Tenure Center, University of Wisconsin-Madison: Madison, WI, USA, 1994.

32. Shimeles, A.; Verdier-Chouchane, A.; Boly, A. Building a Resilient and Sustainable Agriculture in Sub-Saharan Africa; Springer International Publishing: Cham, Switzerland, 2018; ISBN 978331976222.

33. Bezu, S.; Holden, S. Demand for second-stage land certification in Ethiopia: Evidence from household panel data. Land Use Policy 2014, 41, 193-205. [CrossRef]

34. Belay, G. Toolbox for the Development of Cadastral and Registration Proclamation for Second Level Certification Program in Ethiopia. Int. J. Sci. Basic Appl. Res. 2014, 13, 244-259.

35. Crewett, W.; Korf, B. Ethiopia: Reforming land tenure. Rev. Afr. Polit. Econ. 2008, 35, 203-220. [CrossRef]

36. Dessalegn, R. Land rights and tenure security: Rural land registration in Ethiopia. In Legalising Land Rights: Local Practices, State Responses and Tenure Security in Africa, Asia and Latin America; Leiden University Press: Leiden, The Netherlands, 2009.

37. Wabelo, T.S. Legal and Institutional Frameworks Regulating Rural Land Governance in Ethiopia: Towards a Comparative Analysis on the Best Practices of Other African Countries. Beijing Law Rev. 2020, 11, 64-98. [CrossRef]

38. Adam, A.G.; Birhanu, T.A. Decentralised Rural Land Administration in Ethiopia. J. Land Rural Stud. 2018, 6, 34-39. [CrossRef]

39. Belachew, M.; Aytenfisu, S. Facing the challenges in building sustainable land administration capacity in Ethiopia. In Proceedings of the FIG Congress 2010 Facing the Challenges-Building the Capacity, Sydney, Australia, 11-16 April 2010.

40. Deininger, K.; Ali, D.A.; Alemu, T. Impacts of Land Certification on Tenure Security, Investment, and Land Markets: Evidence from Ethiopia; World Bank: Washington, DC, USA, 2008; Available online: https://openknowledge.worldbank.org/handle/10986/6897 (accessed on 8 December 2021).

41. Persha, L.; Greif, A.; Huntington, H. Assessing the Impact of Second-Level Land Certification in Ethiopia. In Proceedings of the 2017 World Bank Conference on Land and Poverty, Washington, DC, USA, 20-24 March 2017.

42. Chekole, S.D.; de Vries, W.T.; Durán-Díaz, P.; Shibeshi, G.B. Analyzing the effects of institutional merger: Case of cadastral information registration and landholding right providing institutions in ethiopia. Land 2021, 10, 404. [CrossRef]

43. MoA National Rural Land Administration Information System (NRLAIS) Implementation Progress Report, Addis Ababa. 2021.

44. DOrsolya, K. Operational Acceptance Test Report: National Rural Land Administration Information System (NRLAIS) Software Operational Acceptance Test Report ver. 1.0 Responsible and Innivative Land Administration in Ethiopia (REILA), Addis Ababa, Ethiopia. 2018.

45. Dečman, M. Factors that increase active participation by higher education students, and predict the acceptance and use of classroom response systems. Int. J. High. Educ. 2020, 9, 84. [CrossRef]

46. Oye, N.D.; A.Iahad, N.; Ab.Rahim, N. The history of UTAUT model and its impact on ICT acceptance and usage by academicians. Educ. Inf. Technol. 2014, 19, 251-270. [CrossRef]

47. Wang, H.-Y.; Wang, S.-H. User acceptance of mobile internet based on the Unified Theory of Acceptance and Use of Technology: Investigating the determinants and gender differences. Soc. Behav. Personal. Int. J. 2010, 38, 415-426. [CrossRef]

48. Nugroho, Y.; Prasetyo, A. Assessing information systems success: A respecification of the DeLone and McLean model to integrating the perceived quality. Probl. Perspect. Manag. 2018, 16, 348-360. [CrossRef]

49. Petter, S.; DeLone, W.; McLean, E. Measuring information systems success: Models, dimensions, measures, and interrelationships. Eur. J. Inf. Syst. 2008, 17, 236-263. [CrossRef]

50. Bakhit Jaafreh, A. Evaluation Information System Success: Applied DeLone and McLean Information System Success Model in Context Banking System in KSA. Int. Rev. Manag. Bus. Res. 2017, 6, 829-845.

51. Zhu, K.; Kraemer, K.L.; Xu, S. The process of innovation assimilation by firms in different countries: A technology diffusion perspective on e-business. Manag. Sci. 2006, 52, 1557-1576. [CrossRef] 
52. Adeyemi, I.O.; Issa, A.O. Integrating Information System Success Model (ISSM) And Technology Acceptance Model (TAM): Proposing Students' Satisfaction with University Web Portal Model. Rec. Libr. J. 2020, 6, 69-79. [CrossRef]

53. Rahimi, B.; Nadri, H.; Afshar, H.L.; Timpka, T. A systematic review of the technology acceptance model in health informatics. Appl. Clin. Inform. 2018, 9, 604-634. [CrossRef] [PubMed]

54. Fathali, S.; Okada, T. Technology acceptance model in technology-enhanced OCLL contexts: A self-determination theory approach. Australas. J. Educ. Technol. 2018, 34, 138-154. [CrossRef]

55. Malik, B.H.; Shuqin, C.; Qamar, S.; Mattiullah, B. Examining Success of Land Record Information Systems (LRMIS) in Pakistan: Validating an incorporated IS success model. Eur. Sci. J. ESJ 2016, 12, 258. [CrossRef]

56. Malik, B.H.; Shuqin, C.; Mastoi, A.G.; Ahmed Ghais, A.H.A. Citizen's Adoption Of Mobile Land Record Information Systems (mLRMIS): A Case of Pakistan. Eur. Sci. J. ESJ 2016, 12, 393. [CrossRef]

57. Ramírez-Correa, P.; Alfaro-Peréz, J.; Cancino-Flores, L. Meta Analysis of the DeLone and MacLean IS sucess model at individual level: An examination of the heterogeinity of the studies. Espacious 2015, 36, 11.

58. McLean, E.; Sedera, D.; Tan, F. Reconceptualizing System Use For Contemporary Information Systems. In Proceedings of the 15th Pacific Asia Conference on Information Systems (PACIS), Brisbane, Australia, 7-11 July 2011.

59. Yu, P.; Qian, S. Developing a theoretical model and questionnaire survey instrument to measure the success of electronic health records in residential aged care. PLoS ONE 2018, 13, e0190749. [CrossRef]

60. DeLone, W.H.; McLean, E.R. The DeLone and McLean Model of Information Systems Success: A Ten-Year Update. J. Manag. Inf. Syst. 2003, 19, 9-30.

61. Contractor, N.S.; DeChurch, L.A. Integrating social networks and human social motives to achieve social influence at scale. Proc. Natl. Acad. Sci. USA 2014, 111, 13650-13657. [CrossRef] [PubMed]

62. Barry, M.; Muhsen, A.; Molero, R.; Muhsen, A.-R. Evolutionary Land Tenure Information System Development: The Talking Titler Methodology Evolutionary Land Tenure. In Proceedings of the 8th FIG Regional Conference 2012 Surveying towards Sustainable Development, Montevideo, Uruguay, 26-29 November 2012.

63. Enemark, S.; McLaren, R.; Lemmen, C. Fit-for-Purpose Land Administration-Providing Secure Land Rights at Scale. Land 2021, 10, 972. [CrossRef]

64. Ijadi Maghsoodi, A.; Saghaei, A.; Hafezalkotob, A. Service quality measurement model integrating an extended SERVQUAL model and a hybrid decision support system. Eur. Res. Manag. Bus. Econ. 2019, 25, 151-164. [CrossRef]

65. Lepmets, M.; Mesquida, A.L.; Cater-Steel, A.; Mas, A.; Ras, E. The evaluation of the IT service quality measurement framework in industry. Glob. J. Flex. Syst. Manag. 2014, 15, 39-57. [CrossRef]

66. Peluso, N.L.; Kelly, A.B.; Woods, K. Context in Land Matters: Access Effects and History in Land Formalization. In Proceedings of the Fourteenth Biennial Conference of the International Association for the Study of the Commons, Mt. Fuji, Japan, 3-7 June 2013.

67. Bollen, K.A. Structural Equations with Latent Variables; Wiley: Hoboken, NJ, USA, 2014. [CrossRef]

68. Population Projection. Available online: https:/ /www.statsethiopia.gov.et/population-projection/ (accessed on 3 December 2021).

69. World Bank. Ethiopia Urbanization Review; World Bank: Washington, DC, USA, 2020.

70. Gavonel, M.F. Patterns and Drivers of Internal Migration Among Youth in Ethiopia, India, Peru and Vietnam; Young Lives: Oxford, UK, 2017.

71. Gashu, A.; Bahir, A. Urbanization and the Struggle for Land in the Peri-Urban Areas of Ethiopia. Available online: http://cega. berkeley.edu/assets/miscellaneous_files/22_-ABCA_Urbanization-research_paper-ABCA.pdf (accessed on 23 September 2021).

72. Knippenberg, E.; Jolliffe, D.; Hoddinott, J. Land Fragmentation and Food Insecurity in Ethiopia. Am. J. Agric. Econ. 2019, 102, 1557-1577. [CrossRef]

73. Soper, D.S. A-priori Sample Size Calculator for Structural Equation Models [Software]. 2019. Available online: http//www. danielsoper.com/statcalc (accessed on 10 June 2021).

74. Ministry of Agriculture and Natural Resources. Technical Specifications-NRLAIS PILOT Note: These Technical Requirements Are Presented in a Format Based on the World Bank International Competitive Bidding template for "Supply and Installation of Information systems". Section VI. Technical Requirements, Responsible and Innovative Land Administration in Ethiopia, Addis Ababa, Ethiopia.

75. Schuberth, F. Confirmatory composite analysis using partial least squares: Setting the record straight. Rev. Manag. Sci. 2021, 15, 1311-1345. [CrossRef]

76. Rose, N.; Wagner, W.; Mayer, A.; Nagengast, B. Model-based manifest and latent composite scores in structural equation models Collabra Psychol. 2019, 5, 9. [CrossRef]

77. Voorhees, C.M.; Brady, M.K.; Calantone, R.; Ramirez, E. Discriminant validity testing in marketing: An analysis, causes for concern, and proposed remedies. J. Acad. Mark. Sci. 2016, 44, 119-134. [CrossRef]

78. Bentler, P.M.; Bonett, D.G. Significance tests and goodness of fit in the analysis of covariance structures. Psychol. Bull. 1980, 88, 588-606. [CrossRef]

79. Hamdan, M.N.M.; Al-Hajri, N.J. The effect of information systems success factors on user satisfaction in accounting information systems. Manag. Sci. Lett. 2021, 11, 2045-2052. [CrossRef]

80. Subaeki, B.; Rahman, A.A.; Putra, S.J.; Alam, C.N. Success model for measuring information system implementation: Literature review. J. Phys. Conf. Ser. 2019, 1402, 077015. [CrossRef] 
81. Al-Fraihat, D.; Joy, M.; Masa'deh, R.; Sinclair, J. Evaluating E-learning systems success: An empirical study. Comput. Hum. Behav. 2020, 102, 67-86. [CrossRef]

82. Kosicka, E.; Gola, A. The Use of QFD for the Design of a Maintenance Service Support System. MATEC Web Conf. 2019, 252, 06012. [CrossRef]

83. Floropoulos, J.; Spathis, C.; Halvatzis, D.; Tsipouridou, M. Measuring the success of the Greek Taxation Information System. Int. J. Inf. Manage. 2010, 30, 47-56. [CrossRef]

84. Machdar, N.M. The effect of information quality on perceived usefulness and perceived ease of use. Bus. Entrep. Rev. 2019, 15, 131-146. [CrossRef]

85. Chaula, J.A.; Institutionen för data-och systemvetenskap (Stockholm). A Socio-Technical Analysis of Information Systems Security Assurance: A Case Study for Effective Assurance; Department of Computer and Systems Sciences, Stockholm University/KTH DSV: Stockholm, Sweden, 2006; ISBN 9171553398.

86. Hsieh, J.J.P.A.; Wang, W. Explaining employees' extended use of complex information systems. Eur. J. Inf. Syst. 2007, 16, 216-227. [CrossRef]

87. Kulkarni, U.R.; Ravindran, S.; Freeze, R. A knowledge management success model: Theoretical development and empirical validation. J. Manag. Inf. Syst. 2006, 23, 309-347. [CrossRef]

88. Chaudhry, B.; Wang, J.; Wu, S.; Maglione, M.; Mojica, W.; Roth, E.; Morton, S.C.; Shekelle, P.G. Systematic review: Impact of health information technology on quality, efficiency, and costs of medical care. Ann. Intern. Med. 2006, 144, 742-752. [CrossRef] [PubMed] 